\title{
Protective masks in a COVID-19 pandemic period: a material analysis for the manufacture of protective masks, use, efficiency, and public strategies aimed at a protection discourse
}

\author{
Ana Elize Oliveira da Silva \\ Graduanda em Engenharia de Materiais, Universidade Federal de Itajubá, \\ Instituto de Engenharias Integradas, Campus Itabira -MG \\ $\triangle$ anaelize@unifei.edu.br \\ Thalita Souza Silva \\ Graduanda em Engenharia de Materiais, Universidade Federal de Itajubá, \\ Instituto de Engenharias Integradas, Campus Itabira -MG \\ $\triangle$ thalita61@unifei.edu.br \\ Adélio Juvêncio Manoel Gonçalves dos Santos \\ Graduando em Engenharia de Materiais, Universidade Federal de Itajubá, \\ Instituto de Engenharias Integradas, Campus Itabira -MG \\ $\triangle$ adeliojuvencio@unifei.edu.br \\ Priscilla Chantal Duarte Silva \\ Doutora em Linguística e Língua Portuguesa, Profa. da Universidade Federal de Itajubá, \\ Instituto de Ciências Puras e Aplicadas, Campus Itabira -MG \\ $\bowtie$ priscillachantal@unifei.edu.br

\section{Ricardo Luiz Perez Teixeira} \\ Doutor em Engenharia Metalúrgica e Materiais, Prof. da Universidade Federal de Itajubá, \\ Instituto de Engenharias Integradas, Campus Itabira -MG \\ $\triangle$ ricardo.luiz@unifei.edu.br

\section{Cristia Rodrigues Miranda} \\ Doutora em Estudos Linguísticos, Universidade Federal de Minas Gerais \\ $\triangle$ cristiamiranda@gmail.com \\ Max Leandro de Araújo Brito \\ Doutor em Energia, Prof. da Universidade Federal do Rio Grande do Norte, \\ Faculdade de Engenharia, Letras e Ciências Sociais do Seridó, Campus Itabira -MG \\ $\triangle$ max.brito@ceres.ufrn.br
}

\begin{abstract}
:
This article has as objective to analyze the public strategies towards the discourses about the use of masks, various present modalities in acts of language and to provide the description of the materials and the analysis of what is really efficient regarding the use of masks. The methodological basis used was the bibliographic review consulted on impact databases by the scientific community. The databases chosen as consultation source were Web of Science and PubMed. For the selection of texts and their analysis, the steps of an integrative review literature (IRL) were developed, as suggested by Souza, Silva, \& Carvalho, (2010), seeking publications about COVID-19 and individual protection masks. As the search keys were pandemic, individual protection masks, Personal protective equipment - PPE and COVID-19 for descriptors and scientific data on the subject were addressed. The result for the analysis for this study makes it possible to assess the type of material most suitable for this protective equipment production, the use of masks by the Brazilian population during the pandemic and the public strategies used in this context. We conclude that the use of a mask depends not only on the type of material used but also on isolation and hygiene measures. Thus, it was verified how emerging public strategies
\end{abstract}


help in the use and greater adherence of protection masks by the population. Although some actions have been implemented in Brazil, the citizen's disobedience and irresponsibility regarding the proper use of protective masks persists.

Keywords: Individual protection masks, COVID-19, Personal protective equipment (PPE), Mask materials. Prevention, Pandemic.

\title{
Máscaras de proteção em período pandêmico da COVID-19: uma análise dos materiais para a confecção de máscaras de proteção, uso, eficiência e estratégias públicas voltadas para um discurso de proteção
}

\begin{abstract}
Resumo:
Este artigo tem como objetivo analisar as estratégias públicas frente aos discursos sobre o uso de máscaras, diversas modalidades presentes nos atos de linguagem e fornecer a descrição dos materiais e a análise do que é realmente eficiente no que diz respeito ao uso de máscaras. A base metodológica utilizada foi a revisão bibliográfica consultada em bases de dados de impacto pela comunidade científica. Os bancos de dados escolhidos para fonte de pesquisa foram Web of Science e PubMed. Para a seleção dos textos e sua análise, foram desenvolvidas as etapas de uma revisão integrativa da literatura (IRL), conforme sugerido por Souza, Silva, \& Carvalho, (2010), buscando publicações sobre COVID-19 e máscaras de proteção individual. Como as chaves de busca eram pandêmicas, foram utilizadas máscaras de proteção individual, Equipamento de Proteção individual - PPE e COVID-19 para descritores e dados científicos sobre o assunto. O resultado da análise deste estudo permite avaliar o tipo de material mais adequado para a produção desse equipamento de proteção, o uso de máscaras pela população brasileira durante uma pandemia e as estratégias públicas utilizadas nesse contexto. Concluímos que o uso de máscara depende não só do tipo de material utilizado, mas também de medidas de isolamento e higiene. Assim, verificam-se estratégias públicas emergentes auxiliam no uso e maior adesão das máscaras de proteção pela população. Embora algumas ações tenham sido implementadas no Brasil, persiste a desobediência e irresponsabilidade do cidadão quanto ao uso adequado das máscaras protetoras.

Palavras-chave: Máscaras de proteção individual, COVID-19, Equipamento de proteção individual - PPE, Materiais de máscara, Prevenção, Pandemia.

\section{Máscaras protectoras en el período pandémico del COVID-19: un análisis de los materiales para la fabricación de máscaras protectoras, uso, eficiencia y estrategias públicas orientadas a un discurso de protección}

\begin{abstract}
Resumen:
Este artículo tiene como objetivo analizar las estrategias públicas en torno a los discursos sobre el uso de máscaras, diversas modalidades presentes en los actos del lenguaje y proporcionar la descripción de los materiales y el análisis de lo que es realmente eficiente en cuanto al uso de máscaras. La base metodológica utilizada fue la revisión bibliográfica consultada en bases de datos de impacto por la comunidad científica. Las bases de datos elegidas como fuente de investigación fueron Web of Science y PubMed. Para la selección de textos y su análisis, se desarrollaron los pasos de una revisión integradora de la literatura (IRL), como sugirieron Souza, Silva, \& Carvalho, (2010), buscando publicaciones sobre COVID-19 y máscaras de protección individual. Como las claves de búsqueda eran pandémicas, se utilizaron máscaras de protección individual, Equipo de Protección Personal - EPI y COVID-19 para los descriptores y datos científicos sobre el tema. El resultado del análisis de este estudio permite evaluar el tipo de material más adecuado para la producción de este equipo de protección, el uso de máscaras por parte de la población brasileña durante una pandemia y las estrategias públicas utilizadas en este contexto. Concluimos que el uso de una mascarilla depende no solo del tipo de material utilizado, sino también de las medidas de aislamiento e higiene. Así, existen estrategias públicas emergentes que ayudan en el uso y mayor adhesión de máscaras protectoras por parte de la población. Si bien se han implementado algunas acciones en Brasil, persiste la desobediencia e irresponsabilidad ciudadana con respecto al uso adecuado de máscaras protectoras.
\end{abstract}

Palabras clave: Máscaras de protección personal, COVID-19, Equipo de protección personal - EPI, Materiales de máscara, Prevención, Pandemia. 


\section{INTRODUCTION}

The world has been facing a disease that causes respiratory infections, Covid-19, a variation of the Coronavirus family. The responsible virus, called SARS-CoV-2, was confirmed by the World Health Organization (WHO) ${ }^{1}$ on January 9, 2020, and since then, the disease has spread intensely around the world. On March 11, 2020, COVID-19 was characterized by WHO as a pandemic (PAHO, 2020).

The Coronavirus disease pandemic has become a significant global concern (ZENG et at., 2020). While a vaccine or a safe and effective medication does not appear, everyone had better adopted measures of isolation and social detachment to contain the exponential advance of the disease. Without the efficacy of pharmacological interventions or vaccines available in the imminent future, infection prevention is the best strategy as an attempt to flatten the contamination curve (CHU et al. 2020).

According to the Ministry of Health, in the treatment protocol for the New Coronavirus (2019 n-Cov, p.9), "coronaviruses are a large family of viruses common in many species of animals, including camels, cattle, cats, and bats". This type coronavirus is highly capable of infecting people and spreading among them, as happened with MERS-CoV and SARS-Co. It is believed that spread from person to person as occurred with MERS-CoV and SARS-CoV, happened mainly through respiratory droplets, similarly to the transmission of influenza and other respiratory pathogens.

The etiologic agent of the New Coronavirus is the RNA virus of the order Nidovirales from the family Coronaviridae. The SARS-CoV, MERS-CoV, and 2019-nCoV viruses are from the subfamily Betacoronavirus that infect only mammals; they are highly pathogenic and responsible for causing respiratory and gastrointestinal syndrome. The clinical spectrum of coronavirus infection is very wide, ranging from a simple cold to severe pneumonia (Ministry of Health, p. 11). The viral diagnosis can be performed by a health professional who will check if the patient has an acute respiratory condition, characterized by a feverish sensation or fever accompanied by cough, sore throat, runny nose and difficulty breathing. If the patient has symptoms, the health professional should request laboratory tests of molecular biology

\footnotetext{
1 The World Health Organization (WHO) declared, on January 30, 2020, that the outbreak of the disease caused by the new coronavirus (COVID-19) constitutes a Public Health Emergency of International Importance - the Organization's highest alert level, as provided for in the International Health Regulations (PAHO, 2020).
} 
Reverse transcription polymerase chain reaction (RT-PCR in real time) ${ }^{2}$. According to the New Coronavirus treatment protocol (Ministry of Health, 2019, n-CoV, p.11), "the referred clinical signs and symptoms are mainly respiratory.

According to some information provided by the Pan American Health Organization (PAHO, 2020), in conjunction with WHO until August 01, 2020, 17.106 .007 cases of Covid-19 were confirmed, (292.527 new cases in relation to the previous day) and 668.910 deaths (6.812 new deaths compared to the previous day).

In addition to a health problem, it is undeniable that the phenomenon has impacted OTHER scenarios: political, social, and economic. In this sense, the relationship between the pandemic and the possible fields makes this health problem, above all, a discourse that reveals political and social strategies, such as social detachment, wearing a mask, discursive attitudes and many other measures. Public strategies to confront the health problem, therefore, reveal, through various linguistic-discursive strategies, the political and social positions that the pandemic problem imposes on the configuration of social stratifications.

In Brazil, until the present date of August 12th, 2020, Covid cases continue in increasing and high exponential numbers, followed by a high mortality rate. According to the Ministry of Health (2020), the number of cases reaches 93,563 (as of August 1, 2020), as shown in the table below:

Table 1- COVID-19 Panel

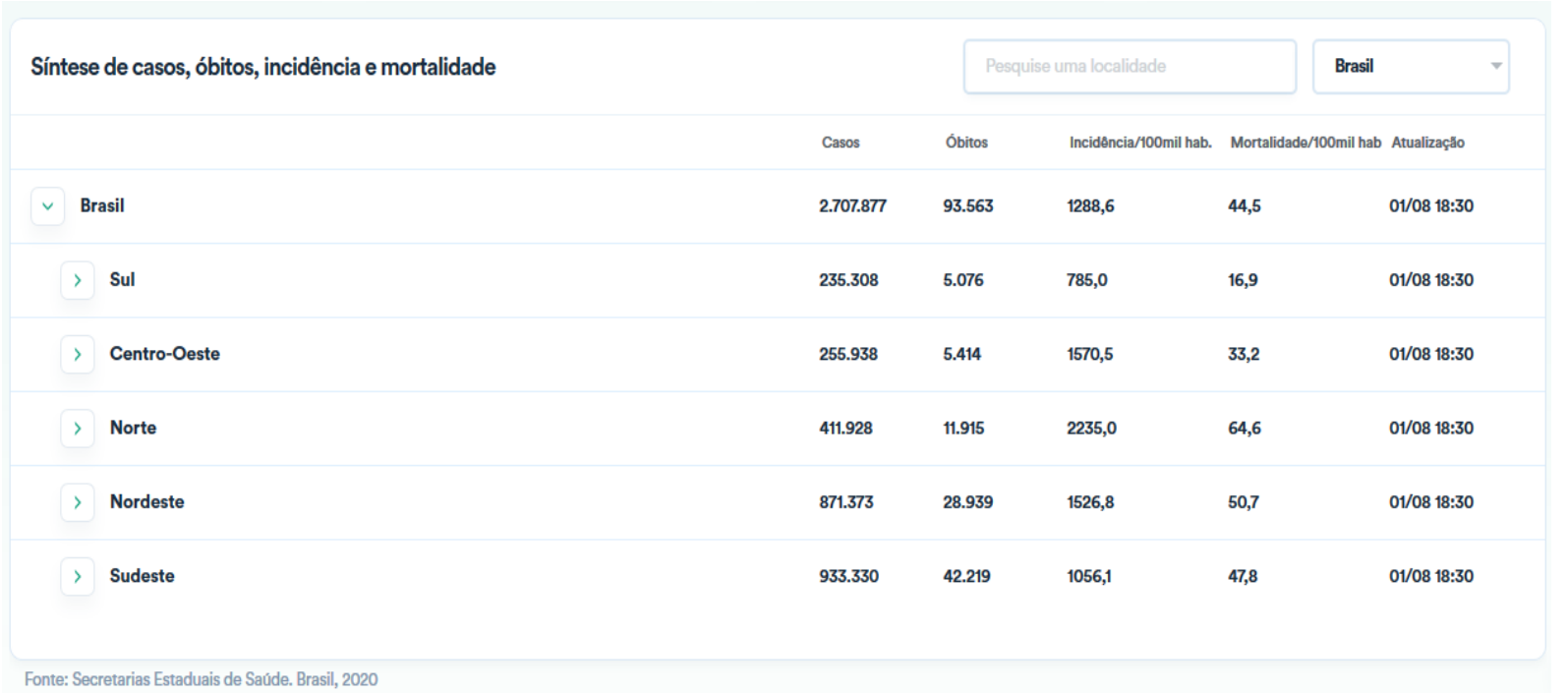

Source: Ministry of Health (2020)

\footnotetext{
${ }^{2}$ Reverse transcription polymerase chain reaction (RT-PCR) is a variation of standard PCR that involves the amplification of specific mRNA obtained from small samples. It eliminates the need for the tedious mRNA purification process required for conventional cloning techniques. In RT-PCR, reverse transcriptase and an RNA sample are used in addition to the standard PCR reagents (MERCK, 2020).
} 
In this context, to prevent the spread of the disease and contagion, preventive measures should be taken, such as improving hand hygiene, practicing social distance, avoiding touching the face, covering the mouth with the elbow when coughing, avoiding crowds, going outside only when needed and wearing protective masks to cover your mouth and nose.

Symptoms created by infectious pathogen, such as sneezing, coughing or bleeding which spread from one person to the others, collaborate to the contagiousness and the increase in the replication number, or "RO"3 of a pathogen. The Imperial College London estimated the R0 of the new coronavirus to be between 1.5 to 3.5 (WALSH, 2020).

As advocated by Li et al. (2020), the transmission routes of the Coronavirus consist of transmissions of droplets, and contacts on contaminated surfaces. Therefore, the masks help to protect us against these possible droplets. Furthermore, with the nose and mouth covered, there is protection if the person takes a contaminated hand to the face. As the viral load is higher in spittle, Zeng et. al. (2020) points out that there is a greater risk of viral transmission in usual behaviors such as conversations and eating. Wu et al. (2020) also confirmed in studies that it is possible to have respiratory transmission when speaking.

For this reason, social distance is a relevant preventive measure. After the discovery that asymptomatic people could also transmit the virus, the use of masks has also become an efficient practice to reduce the spreading of the virus. An important characteristic that, perhaps, was crucial for the progress of the disease: ignorance, negligence and asymptomatic cases. According to Qiu (2020), the proportion of asymptomatic people is high. About $60 \%$ of all cases are between mild symptoms and asymptomatic cases that can transmit the virus to other people.

Steffen et. al. (2020) highlight that for both cases of asymptomatic people and people infected with the Coronavirus, the use of masks is essential. However, studies indicate that

\footnotetext{
${ }^{3} \mathrm{R}_{0}$, pronounced " $\mathrm{R}$ naught," is a mathematical term that indicates how contagious an infectious disease is. It's also referred to as the reproduction number. As an infection is transmitted to new people, it reproduces itself. $R_{0}$ tells you the average number of people who will contract a contagious disease from one person with that disease. It specifically applies to a population of people who were previously free of infection and haven't been vaccinated. For example, if a disease has an $\mathrm{R}_{0}$ of 18 , a person who has the disease will transmit it to an average of 18 other people. That replication will continue if no one has been vaccinated against the disease or is already immune to it in their Community (HEALTHLINE, 2020)
} 
airborne transmission may also be possible in specific circumstances and configurations, including aerosols (Wang et al., 2020), which demands the use of eye protection as well.

According to the Institute of Hygiene and Tropical Medicine at Universidade Nova de Lisboa, the protection of the visors used to fight the Coronavirus consists of protection against the projection of solid and liquid particles to the face, mouth, nose and eyes. "It is reusable and must involve the face, covering the forehead, extending below the chin, and involving the side of the face. It must guarantee good sweating behavior; be made of unbreakable material, with adjustable tape" (Conceição, 2020). Wang et al. (2020, p. 1) warn that "the drop could enter the susceptible mucous surface at a certain distance (usually less than $1 \mathrm{~m}$ )", so the distance associated with individual protection from the use of masks and protectors (visors) is the recommended procedure.

\begin{abstract}
The droplets are larger than $5 \mu \mathrm{m}$ (micrometers). Each micrometer is equivalent to the millionth part of the meter. They can reach the upper respiratory tract, that is, the mucosa of the nasal cavities and the mucosa of the oral cavity. In aerosols, the particles are smaller and remain suspended in the air for long periods. When inhaled, they can penetrate more deeply into the respiratory tract. There are respiratory transmission diseases by droplets and aerosols that require different modes of protection. (ANVISA, 2020)
\end{abstract}

At the beginning of adherence to social isolation, the use of protective masks was recommended only for health professionals and people with flu-like symptoms. However, its use by everyone was gradually proposed by the Ministry of Health and, later, it became mandatory in some regions. "The mandatory use of masks is determined, within the Federal District, due to the pandemic of COVID-19, caused by the new coronavirus" (BRASIL, 2020). This change was a consequence of the observation of the use of this equipment in other countries, the result of research on its effectiveness, and also due to the study of asymptomatic people cases, who could also infect other individuals

Zeng et. al. (2020) highlight that, considering the analysis of the epidemiological curves of China, South Korea, Italy, and Spain, one can observe the importance of the use of masks by the population. According to China's epidemiological characteristics, as shown in Fig. 1, on the night of January 20, 2020, when it was announced that COVID-19 could be transmitted from person to person, the majority of the population started wearing masks while in public on January 21st. This contributed to curb the number of cases, according to 
the authors. Other studies have also found evidence regarding the effectiveness of wearing masks in reducing the risk of SARS and influenza-related illnesses (Jefferson et al., 2009).

Figure 1. Epidemiological curves for China (A, B), Guangdong (C) and Shanghai (D)
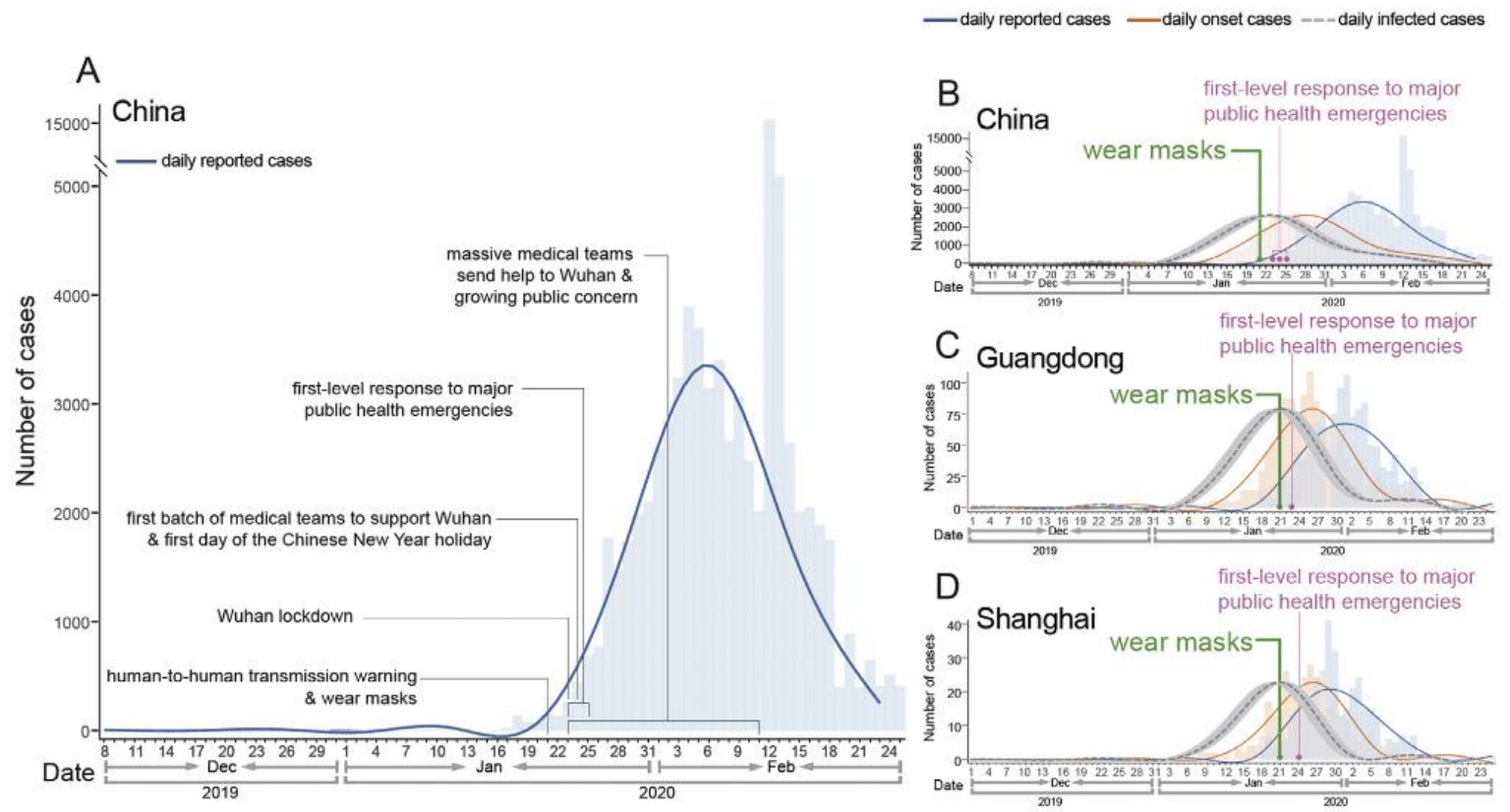

Source: Zeng et al. (2020).

The fact is that there is a lot of controversy and lack of consensus across cultures about the use of facial masks, as well as the effective use of them (Wang et al., 2020). This has hindered both the reduction of the spread rate and the effective control of the disease. In this regard, effective public strategies are needed to raise public awareness. According to PAHO (2020), "15,012,731 cases of COVID-19 (247,225 new in relation to the previous day) and 619,150 deaths (7,097 new in relation to the previous day) were confirmed worldwide by July 23, 2020".

It is in this context that public strategies, as speeches per se, are important as measures to contain the disease. As actions, programs, plans and decisions taken by governments, public strategies to combat coronavirus can assume a role of representing what happens in relation to the spread of the disease to other countries. In this sense, this study analyzes the performance of these strategies in Brazil.

Wang et al. (2020) highlight that there are two controversial situations regarding the discourse on the use of individual protection masks by the population. On one hand, there is 
an incentive to use masks in public places, as a relevant discourse on health-seeking behavior, as confirmed by Greenhalgh1s et al. studies (2020). On the other hand, there is panic, and the discouraging towards the use of masks by some health authorities on the grounds that masks do not offer effective protection, as pointed out by Feng et al. (2020).

In Brazil, at the beginning of the pandemic, there was no discussion about the use of masks. Alcohol gel was the target product and the protective reference, subsequently, were the surgical masks. In some places, there was a shortage of both $70 \%$ alcohol gel and disposable face masks. When the number of cases began to rise exponentially, the Ministry of Health recommended individuals to wear homemade masks produced with fabric, to replace surgical or disposable masks. Subsequently, wearing individual protective masks in public places was enacted.

The misuse and observation of individuals wearing low or no effectiveness masks in a pandemic situation also motivated the elaboration of this study. In addition, it is important to highlight the link that the authors have with the theme, due to the interest in protective materials and their properties. It is believed that the technical understanding on the subject, as well as the analysis of the public strategies involved in combating COVID-19 in Brazil, can help to inform the population and contribute to the use of the correct equipment consequently, minimizing the growth of the infection rate.

Therefore, the objective of this research is to analyze the public strategies aimed at the discourses on the use of masks and the many modalities present in the acts of language and speech. As this is a multidisciplinary research, the different types of materials used in the manufacture of homemade, surgical, class $\mathrm{N}$ and face shield masks are technically analyzed, their performance and effectiveness, as a method of preventing coronavirus, regarding the use and public strategies involved in the pandemic period. In addition, it gives suggestions for the use of face masks during the COVID-19 epidemic.

\section{MATERIALS USED IN THE MANUFACTURE OF PERSONAL PROTECTIVE MASKS}

In a pandemic period, several parts of the world asked the Chinese industries to produce and export PPE, as they are the largest manufacturers of this equipment (Soares, 2020). However, it was necessary to stick to one composition and to decide which the best material was, considering its characteristics, properties and efficiency. The most important 
and best-known protection accessories are the masks: homemade, surgical, Class $\mathrm{N}$ and Face Shields.

The homemade masks are manufactured mainly from cotton fabrics, as instructed by the Ministry of Health, such as tricoline, which has natural fiber with a length of variation between $24 \mathrm{~mm}$ and $38 \mathrm{~mm}$ and a fibrillar structure that works as a protective barrier. Its composition consists mainly of cellulose.

Thus, their physical and chemical properties are subordinated to this factor. This option offers advantages, has resistance and durability, it does not prevent sweating and it does not cause sensitivity. It is suitable for making homemade masks thanks to the dense content, which provides greater protection. In addition, as a secondary material, elastic is used, a synthetic fiber fabric to keep it suspended on the face, composed of elastane and polyester threads.

Figure 4 - Homemade mask

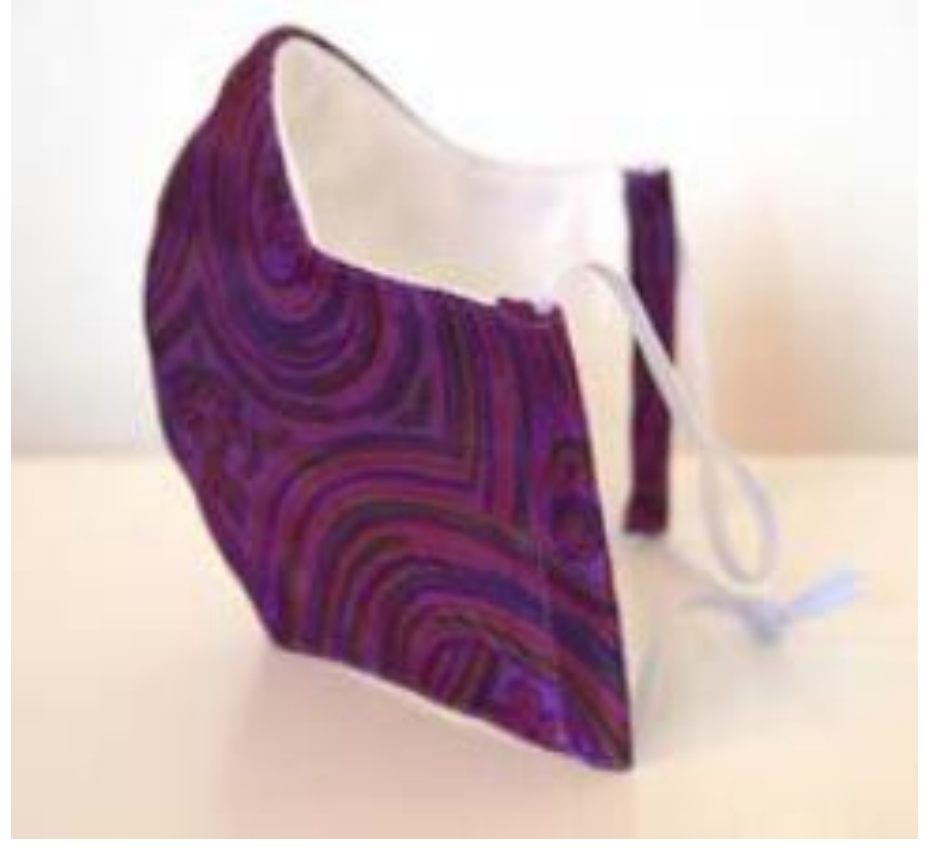

Source: Mills et al. (2020).

Another widely used material is TNT Fabric, both for surgical masks and for Class N masks, such as N95, and its correspondent in Brazilian standards, PFF-2. Since SARS-CoV-2 has an approximate size of 120 nanometers, this equipment has several layers to increase the 
efficiency in the retention of viral particles, which must be resistant to the penetration of air fluids, in addition to being properly adjusted in the face (Franco, 2020).

TNT Fabric consists entirely of polymer, polypropylene, which has a molecular formula (C3H6) n, a by-product generated by oil refining. It is a low-density resin with a high softening point, in addition, its physical, chemical, and thermal properties are in constant balance. The polymer is non-toxic, it is low cost, simple molding, it has chemical stability, and it is resistant to fractures, properties that contribute to this fabric being widely used in the production of masks. However, the simple manufacturing process is also a factor that contributes to its choice, as it is not necessary to tear the fibers, as most of them are heatwelded with continuous filaments.

Despite using non-woven fabric, masks have differences in composition. The surgical has three layers, the inner one with the primary purpose of retaining particles, but also aims at skin comfort, the intermediate with Melt Blown filter, a polypropylene microfiber technology, material with excellent mechanical properties, low cost and processing facility produced under strict control to keep it uniform and stable with the ability to create a high flow porous medium (Quental, 2016) and the third layer similar to the first, protects against moisture. This mask is sterilized by ethylene oxide $(\mathrm{C} 2 \mathrm{H} 4 \mathrm{O})$ by means of protein alkylation.

Figure 5 - Surgical mask

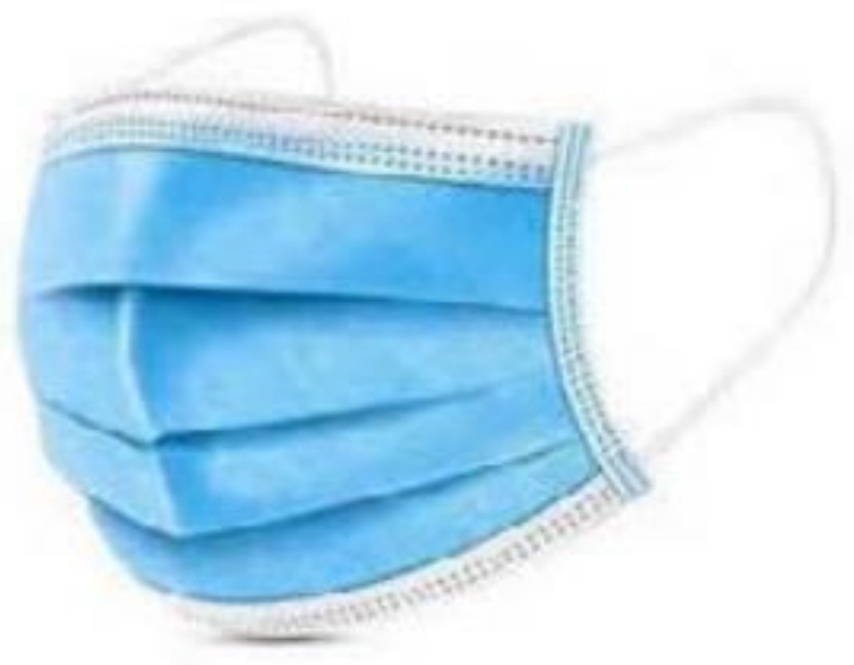

Source: Mills et al. (2020). 
Class N mask, especially N95, can filter all types of particles. The number of layers may vary, but has an average of 5 , the first of which is non-stick with microfiltration, the second and third have an activated carbon filter capable of retaining even smaller particles than the viral ones, the fourth reduces the density of small substances and the fifth is also non-stick. But despite the protection afforded by the layers, when reusing the equipment, it is important to stick to the structure, adaptation to the face and the possibility of there being remnants of bodily fluids (Duarte, 2010).

Figure 6 - Mask N95

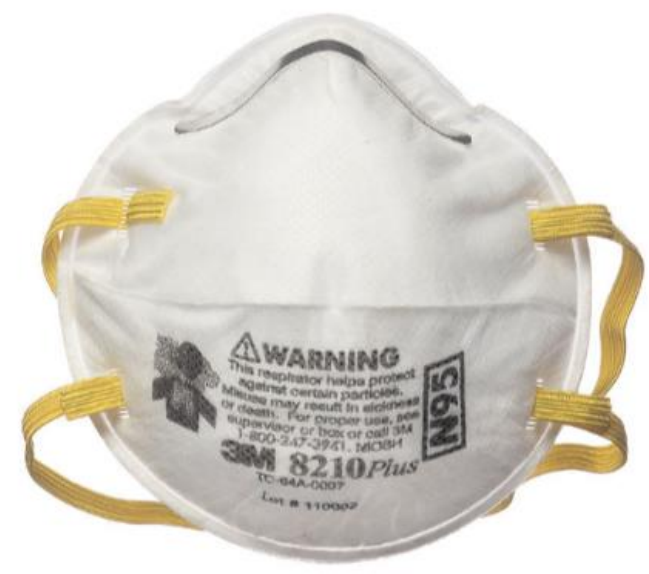

Source: The New York Times (2020).

In addition to these, there is the Face Shield, it is an easily manufactured protector since the materials used are found on the market at low cost. The materials are acetate films, Polyethylene Ethylene Terephthalate Glycol - PETG, polycarbonate and acrylic, and all have properties of transparency and are non-toxic. This equipment is a great ally of frontline professionals because it protects the entire face. Given its importance, projects have emerged, such as Face Shield for Live 3D, in which volunteers are available to produce and distribute free of charge to health professionals (Jorge, 2020).

The films, composed of cellulose acetate (C76H114O49), an ester that has flexibility after the acetylation process by removing the hydroxyl from the last group of the polymeric chain, have resistant fibers up to $80^{\circ} \mathrm{C}$. In addition, the material gives the films properties of flexibility, great resistance, hardness, and impermeability. PETG, a material obtained through the copolymerization process of Ethylene Polyterephthalate (PET), has thermal stability, 
resistance, the ability to absorb impacts and the advantage of not being compromised by alcohol esterification.

Polycarbonate is a thermoplastic polymer derived from Carbonic acid and Bisphenol, and due to the presence of benzene in the structure, the material is rigid with resistance to impacts. Acrylic $\left(\mathrm{C}_{5} \mathrm{H}_{8} \mathrm{O}_{2}\right) \mathrm{n}$, an additional polymer, is obtained from the methyl methacrylate monomer, its composition provides good strength, flexibility, and durability. Despite presenting quality properties, the mask produced by this material is less efficient than the others mentioned.

Figure 7 - Face Shield

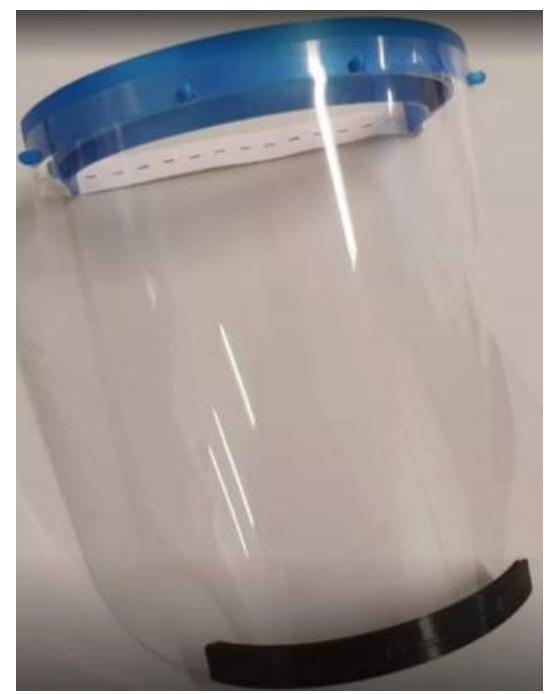

Source: Gomes et al. (2020).

\section{THE USE OF PROTECTIVE MASKS AS A METHOD OF PREVENTING CORONAVIRUS}

Masks are tools widely used by people with respiratory problems, but with the arrival of a new virus it has become a mandatory resource to be worn so that there is no further spread of this disease. The World Health Organization (WHO, 2020) decreed the use of masks for professionals and people who are sick, but it was adopted by a large part of the population when going to public places, such as supermarkets, pharmacies, and public transportation.

However, good use does not depend only on masks to avoid contagion, because in addition to variation in filtration, the way to handle them must also be considered, as it is 
necessary to adopt hygienic measures, such as the need to be careful when removing them. As the virus is transmitted not only by the droplets that fall and stay in the environment, but also by those that stay in the air, the daily use of this protection is necessary. Studies confirm the presence of the virus in saliva aerosols, which are small liquid particles carried by the environment. Different from saliva droplets that fall on surfaces, aerosols can be suspended in the air for a few hours (Ministry of Health - protocol 2019 -NCoV).

However, it should be noted that there are positive and negative sides towards he uses of masks by people who are not contaminated, such as self-contamination, which can occur when the person is handling the mask with viral particles, possible breathing difficulties, a false feeling of safety, or its use can potentially lead to a less compliance behavior with other precautions, such as physical distance and hand hygiene. One of the possible advantages observed is that it reduces the risk of transmissions from infected people and in the presymptomatic stage.

There is concern about the scarcity of surgical masks on the market due to increased demand, as they are of paramount importance for those on the front lines. Because of this fact, as suggested by the Ministry of Health ${ }^{4}$, the population should make use of homemade, leaving the surgical and third-level filters for health professionals.

To make homemade masks, it is necessary to have at least three layers of fabric in their composition, one of which must contain absorbent material, such as cotton, can be made of fabrics such as vacuum cleaner, cotton, and antimicrobial fabric pillowcases. It is noteworthy that its use is unique and cannot be shared, even with people of the same family. Also, after two hours it is necessary to exchange it. The homemade mask must be previously sanitized by the individual, and it must be cleaned with bleach and soaked for approximately 30 minutes, according to instructions from the Ministry of Health.

\footnotetext{
${ }^{4}$ When the professional acts in procedures with risk of aerosol generation in patients with suspected or confirmed infection by the new coronavirus $(2019-\mathrm{nCoV})$, they must use the respiratory protection mask (personal respirator) with minimum efficiency in the filtration of $95 \%$ of particles up to 0.3 (type N95, N99, N100, PFF2 or PFF3) (MINISTRY OF HEALTH - PROTOCOL 2019-NCoV)
} 


\section{INDIVIDUAL PROTECTION MASKS AND THEIR EFFECTIVE USE ACOORDING TO THEIR TYPE OF MATERIAL}

Based on the results of research proving that the use of protective masks can be effective in preventing Coronavirus, health entities began to recommend their use. In this way, several professionals researched which materials are the most efficient to serve as a barrier to the virus, while providing greater comfort for the individual, and having greater particle retention capacity. It became necessary to study materials whose cost and production would meet the demand of the general population for the manufacture of effective homemade masks, when compared to the performance of masks for professional use.

To test the particle retention capacity of protective masks, the University of Cambridge conducted a survey in which scientists fired 0.02 micrometer MS2 Bacteriophage ${ }^{5}$ particles, six times smaller than the coronavirus, which is only 120 nanometers in length, in different household materials to find the best feedstock for the manufacture of homemade masks. It was verified that the cotton fabric retains $70 \%$ of these particles. The researchers also tested the individual's ability to breathe using the cotton mask, measuring the pressure drop in each type of tissue when compared to the surgical mask. The result obtained was that, using the homemade mask, the ease of breathing is $2 \%$ greater than that of the surgical one, which makes cotton the most suitable fabric in the manufacture of this homemade protective equipment, being recommended the use of three layers of material (Robertson, 2020).

Chu et al. (2020) evaluated the use of a face mask versus its absence to prevent influenza-like illnesses in healthcare professionals. They used Bayesian meta-analysis ${ }^{6}$ to reinterpret the effectiveness of $\mathrm{N} 95$ respirators $^{7}$ versus medical masks in preventing influenza-like illnesses after seasonal viral infection. The authors point out that the use of N95 or similar respirators or face masks (for example, similar reusable 12-to-16-layer cotton masks) by those exposed to infected individuals were associated with a great reduction in the risk of infection.

\footnotetext{
5 The Escherichia MS2 virus is a positive icosahedral single-stranded RNA virus that infects the bacteria Escherichia coli and other members of Enterobacteriaceae. MS2 is a member of a family of bacterial viruses. E. coli bacteriophage MS2 (ATCC 15597-B1), a single-stranded RNA coliphage, was selected as a model virus in this study.

${ }^{6}$ Meta-analysis can be defined as a statistical procedure that consists of a quantitative and summarized review of the results of different studies, but which are related. Bayesian methods are alternative techniques to classic models of statistical inference. The idea is to combine information a priori with information from sample data (MANCUSO, 2010)

${ }^{7}$ An N95 mask or an N95 respirator is a particulate filter breathing mask that meets the N95 standard of the US National Institute of Occupational Safety and Health air filtration rating.
} 
The association with protection against infection was more pronounced with N95 or similar respirators about Reporting adjusted odds ratios (aOR) 0.44 , and $95 \%$ confidence intervals (CI) 0.004 to 0.30 compared to other masks (aOR $0.33,95 \%$ CI 0.17 to 0.61 ), according to the authors, who, in addition, draw attention to the importance of social distance. So, face mask use could result in a large reduction in risk of transmission. For exposed individuals, N95 or similar respirators or face masks (eg, disposable surgical masks) were associated with reduced infection risk (OBG Project, 2020). N95 has a better protection considering exposure risks. They found that virus transmission was less with a physical distance of $1 \mathrm{~m}$ or more, compared to a distance less than that. The protection increased as the distance increased, in a direct proportion.

However, it is important to note that homemade masks do not have the same efficiency as the equipment recommended for professional use. Because the fabric has a more open textile structure, when compared to TNT Fabric, used in the manufacture of surgical and class $\mathrm{N}$ masks, it can be said that there is a greater possibility of contamination by the virus because it is able to overcome the barrier of protection (Medeiros, 2020).

Thus, masks for professional use should be worn by laborers who work in the health field and who are directly facing the disease, as they need greater protection against the virus. The equipment indicated for the use of these individuals is made of polypropylene TNT and is called surgical and class N masks. The University of São Paulo carried out a research that consisted of testing the filtering capacity of the materials used in the manufacture of these masks by means of a measuring equipment, which consists of an aerosol generator that supplies particles the size of the coronavirus and an electronic system of particle detection. The result was that surgical and N95 masks have the capacity to retain up to $97 \%$ of the particles, which makes them ideal for exercising this function. (Bernardes, 2020).

According to European Committee for standardization (2001), EN 149 - Respiratory protective devices - Filtering half masks to protect against particles - Requirements, testing, marking is European Standard that specifies the minimum requirements for filtering half masks used as respiratory protective devices, specifically against particles, and the required laboratory and practical performance tests to assess masks' compliance. Half masks used for escape purposes are excluded from the scope of this standard.

\footnotetext{
${ }^{8}$ The odds radio is a measure of the odds of an event happening in one group compared to the odds in another group. Usually seen in case-control (retrospective) studies to determine if a certain exposure is associated with a risk of a particular outcome. An odds radio o fone means there is likely no change in risk of a particular outcome or event. An odds ratio of greater than one means there is an increased risk and less than oen means that the exposure reduces the risk (obgproject.com).
} 
Under the preceding EN149:1991 standard, the classifications were FFP1S, FFP2S, FFP2SL, FFP3S and FFP3SL. EN149:2001 classified half masks into three types according to their filtering capacities (e.g., FFP1, FFP2, and FFP3). Respirators that meet the requirements of EN149:2001 are designed to protect against solids, water-based aerosols, and oil-based aerosols.

The PN-EN 149: 200 standard defines three protection classes: filter facepiece 1 (FFP1); filter facepiece 2 (FFP2) and filter facepiece 3 (FFP3). According to the authors, the maximum internal leakage limit is $25 \%$ for FFP1, $11 \%$ for FFP2 and 5\% for FFP3. As for protection, Class FFP1 masks retain about $80 \%$ of particles smaller than $2 \mu$ m, FFP2 retain $94 \%$ of particles smaller than $0.5 \mu \mathrm{m}$ and FFP3 retain $99.95 \%$ of particles smaller than $0.5 \mu \mathrm{m}$.

Table 3 - Filtering efficiency for each mask class

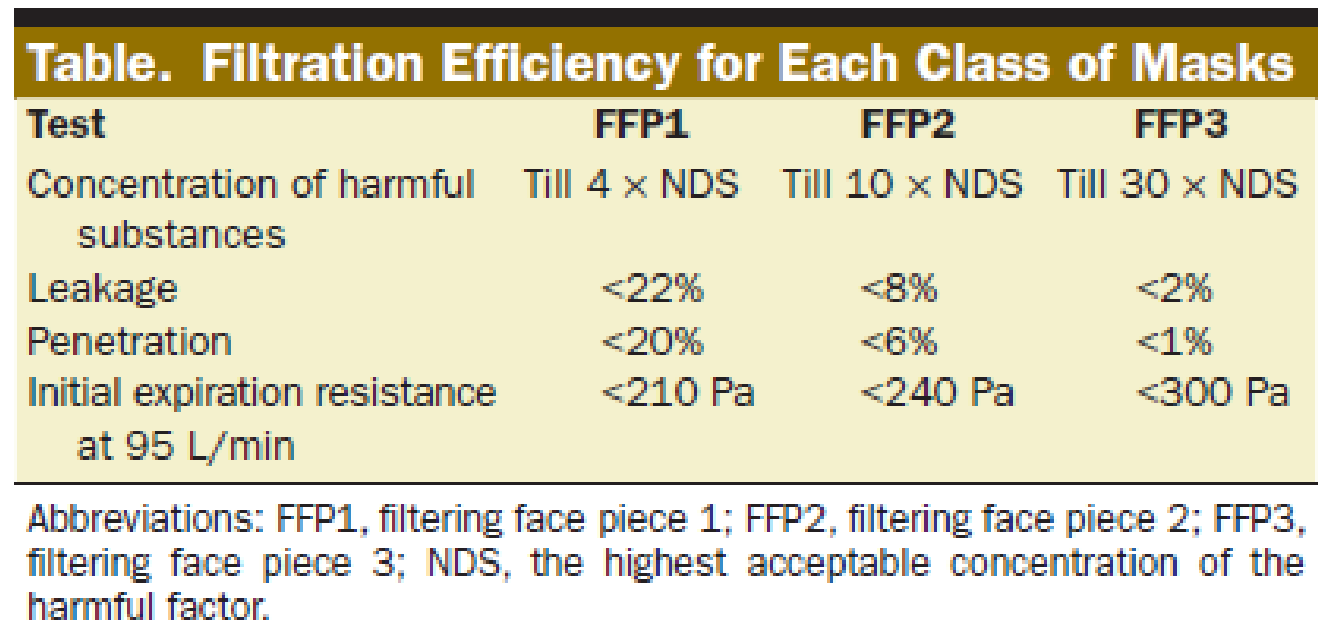

Source: Smereka et al. (2020).

Surgical masks are designed to protect against droplets or particles with a diameter> $100 \mu \mathrm{m}$. The coronavirus 2 severe acute respiratory syndrome virus (SARS-CoV-2), however, is essentially spherical, although slightly pleomorphic, with a diameter of $60 \mathrm{~nm}$ to $140 \mathrm{~nm}$ and 100 times smaller than the diameter of the pores. Surgical masks, in the authors' view, cannot prevent the inhalation of small airborne particles; they only protect emissions from large drops and sprays (Smereka et al., 2020).

In addition to these mask options, there is also the face shield, a transparent protector that covers the entire face region. It is adjustable to the person's face, providing comfort to 
the individual who uses it, in addition to being reusable and easy to clean. Due to the properties of the materials used in its manufacture, the result is a resistant physical barrier in protection against particles. Its use is complementary to the professional mask, thus reinforcing the protection of individuals working in the health area. However, due to the care taken against Covid-19, its use also extends to other workers, such as supermarket attendants. Thus, the use of masks has become an efficient preventive measure against coronavirus, serving as a barrier against secretions that can contaminate the population. Although not all of them have maximum efficiency, their use is mandatory and prevents contamination when combined with other preventive measures.

\section{PUBLIC STRATEGIES CONCERNING THE USE OF PERSONAL PROTECTIVE MASKS AGAINST COVID-19}

With the accelerated pandemic advance, the use of protective masks has come to be treated as a public health issue. Based on the positive results presented regarding this equipment against COVID-19, countries started to implement public strategies in order to encourage their wearing to reduce the contamination rate.

Public service performance strategies, which were called "public strategies" for the purpose of this article, are structured through decision-making processes that involve the complex variables that have practical effects on society (Silva and Lima, 2017). Regarding the confrontation of the pandemic, the Brazilian government gave autonomy to the states and municipalities over the inspection and procedures to contain and control the pandemic.

However, the provisional measure, n. 926 of 2020, amends Law No. 13,979, of February 6, 2020, which "provides measures to deal with public health emergencies of international importance due to the coronavirus responsible for the 2019 outbreak". It provides, exceptionally in a temporary way, some restrictions related to highways, ports, airports, entry or exit from the country, besides interstate and intercity transportation. It gives the President of the Republic the power to dispose, by decree, of essential community services.

Government measures have emerged to guarantee the use of protective masks for the population, with the aim of reducing the risk of contagion and avoiding a possible new wave of contamination. To this end, it was generally decreed in most cities that citizens should wear this equipment in public places. Thus, to ensure that this obligation is fulfilled, 
inspection measures and the application of fines for those who violate this decree must be implemented. In other countries, for example, inspections are carried out by health surveillance. The citizen who is not wearing protection is advised on the need for its use, and, in some cases, may be given a mask. If the accessory is not wearing after the warning, a fine is applied according to local law. However, in Brazil, the mandatory mask use was mainly enforced within commercial establishments.

In addition, awareness campaigns were launched to inform the population about the use of masks, such as advertisements on television channels. Their job is to spread a protective speech like "the mask saves lives" to encourage the population to protect themselves and prevent the spread of the virus.

The Ministry of Health also made some information available on its website, for instance: what is COVID-19, symptoms, diagnosis, forms of protection, health services, informing the places of care by SUS - Single Health System, and frequently asked questions, along with support materials such as a special phone number managed by Health professionals for clarifying some doubts about COVID (Disque Saúde 136), mobile applications, epidemiological bulletin, fake news reports, child development material and guidelines for safely resuming activities. However, some do not necessarily portray COVID-19 prevention guidelines. In this sense, there is a greater need to extend COVID-19 prevention campaigns. The reports of the transmission, deaths and recovery rates are disseminated and updated by the COVID-19 Panel, also on the Ministry of Health website.

For the population to protect itself from the Coronavirus, the government must provide financial investments for research and development of technologies that can be used to slow the spread of the disease. Finep - Financing of Studies and Projects, it is a Brazilian public company that promotes science, technology and innovation in companies, universities, technological institutes and other public or private institutions. Finep promotes the economic and social development of Brazil by publicly promoting Science, Technology and Innovation in companies, institutions, technological institutes and other public institutions or institutions. It's a public company linked to the Ministry of Science, Technology, Innovations and Communications - MCTIC, and FAPESP (Research Support Foundation of the State of São Paulo) launched a public funding to support researchers focused on technology to reduce the Coronavirus contamination rates, such as the 
development, improvement and production acceleration of equipment for individual protection (Negri and Koeller, 2020).

A study published in the Proceedings of the Royal Society proves, from different approaches, that the use of masks, even those that have low efficiency, are great allies to help control the number of infected and even more effective if used by the entire population, especially because many people do not show symptoms (Stutt, 2020). However, despite the public health policies cited, the numbers of contaminated individuals are still high in several countries, due to the delay in recommending the widespread use of masks, which was done on June 5,2020 by the WHO period in which many regions have already had decreed a state of calamity (Fioratti, 2020).

As an example, Vietnam, which decreed the mandatory use of masks across the country on March 16, 2020, until July had no deaths caused by the coronavirus (O 'Grandy, 2020). However, United States, which does not have a nationwide decree mandating the use of this safety equipment, has more than 3,910,300 cases of contamination and 142,031 deaths as of July 22, 2020, according to data from The New York Times (2020). Thus, encouraging the use of masks has also been successful in combating SARS-CoV-2.

However, it is evident that there is a variable number of people who refuse to wear a mask or handle it incorrectly, thus causing non-compliance with the rules imposed by WHO and the Ministry of Health. In the same line of thought, it is noted that people have the right to self-determination of choices, as provided for in the 1988 Constitution which expressly recognizes the right to freedom and individuality when it comes to fundamental rights. Individual freedom mentions that no one will be obliged to do or fail to do anything except under the law (art. 5, II, CF / 88). The individual reasons are greater than the reasons of the State, however, individual freedom may suffer some restrictions when they meet the collective well-being and the commitment to the preservation of health that is guaranteed to all.

Bearing in mind the importance of wearing masks in critical situations such as a pandemic, it should only be a conscious practice without the need for legislative intervention. One who does not submit oneself to the mandatory mask use not only increases the contamination danger to oneself and to the others, but also make it a great contagion factor.

The use of a mask is not a prevention only for those who wear it, a fact that should be reinforced with public education campaigns. This was already stated above regarding the 
WHO statement on the use of surgical masks and the N95 type, which consists of giving priority use of these products to sick individuals and to people who work fighting the virus on the front line.

Ordinary citizens, following instructions from the Ministry of Health, opted for the use of homemade masks, which, being able to be made through artisanal manufacture, became popular. These homemade masks were also customized with different types of printed fabrics, as long as they follow the manufacturing standards for masks imposed by Ministry of Health. Many informational contents were made available on the internet and in the media to assist the population. Although this collective effort has been noted, there is still a lot of non-compliance with the guidelines and a pervasive lack of awareness among citizens regarding public strategies to confront the pandemic in Brazil.

Public strategies are present on discourse. When analyzing the discourses that move the policies for implementing the use protective equipment, is possible to see the modalitization marks, around the discourse about the use of masks. It moves around its need and responsibility. The discourse, about wear of masks talks about the instruction - the correct use of masks, and an obligation. It circulates the notion that, protecting yourself, you will be also protect another people. The speech about the use of masks became part of the set of speeches that involve the individual's responsibilities as a citizen. Thus, wearing the mask became part of citizen ethics. Some linguistic approaches advocate that every discourse involves an action. Often, the speech itself is an action. Thus, in speeches about wearing a mask, it is possible to observe an action of making the other act. This action is manifested in the speech. On speech it is possible to observe marks of subjectivity. On speech it is possible to observe marks of subjectivity. and it can be observed by lexical (words) chosen. Thus, as forms of language guide and conduct the meaning.

The Acts of Speech, Austin (1981) recognize acts in the language. Every Speech Act moves language in a certain direction. Modalizations are linguistic marks that allow to recognize the presence of the speaker in the statement. On speech, the speaker reveals your ideas, your point of view. For Ducrot (1987), the idea, dictum (representation), or propositional content (the semantic value of a given statement), consists of nothing but one or more positions taken.

Deontic modalization (Neves, 1996, Koch, 2004, Castilho, 1992) is the category (name) linguistic that recognizes the intention linked to - the duty to do - to the need and the 
obligation. In this sense, speeches on the use of masks reveal this intention that arises from these verbal forms related as public strategies for health confrontation through the pandemic. An example of this would be the statement of Agência Brasil's ${ }^{9}$ website, published by Valente (2020): Text [1] "Covid-19: Brazil adopts the use of masks as a public health policy: know where the use of masks is mandatory in Brazil".

In the text of the Presidency of the Republic (2020), the following is observed in: Text [2] "Learn how to protect yourself". In other words, this text highlights that the requirement to wear a mask is a public strategy because it involves public action as it is a duty, following the argument that the use of masks means self-protection.

Deontic acts are, therefore, configured here as legal acts that result in the creation of needs (rights) and duties in speech acts. Examples of deictic marks are attitude verbs. With: (1) "Ask questions about the mandatory use of a mask in SP: as of July, people and establishments may be fined by the Health Surveillance; these fines will cover the food baskets that will be distributed through the Solidarity Food program" (Do Governo Portal, 2020); (2) Public agencies and entities, concessionaires of public services, such as transportation, and the private sector of goods and services should adopt hygiene measures in places where people circulate and inside vehicles, providing sanitizing products to users, such as alcohol gel (Presidency of The Republic, 2020).

In this case, through attitude verbs such as "take away" and "they may be fined", it is possible to perceive the attitude taken by the speaker to the enunciative scene, assuming the position those who, through the propositional content contained in the idea the obligatory nature wearing masks, institutes this influence relationship on the interlocutor. The speaker puts himself in the position of assertion agent of rights and duties that, at the same time, proposes to the interlocutor, the legal act itself, which Ducrot (1987) deals with: "if on the one hand there is an interlocutor who places himself in the position of donor or solicitor, asserver, or questioner, on the other hand, this position also defines the interlocutor" (Neves, 2006; Ducrot, 1987).

\footnotetext{
9 Agência Brasil is a website linked to Empresa Brasil de Comunicação (EBC). EBC is a federal public company, created by Law No. 11,652 / 2008 and amended by Law No. 13,417 / 2017, which gives effect to the constitutional principle of complementarity between the public, private and state systems of communication. The company fulfills its role as a service provider and contributes to the objective of broadening the public debate on national and international issues, of promoting the construction of citizenship, with an educational, inclusive, artistic, cultural, informative, scientific, and public interest program, focusing on the citizen.
} 
Even without the deontic modalization marks ${ }^{10}$, through attitude verbs, the relationship between the context, the speaker's intention and the effect caused on the recipient can be seen in the highlighted passage that this relationship, as pointed out by Parret (1988), is constructed by the exchange situation and the context. In other words, the modalization takes place through the context about the information on the application of fines, and the description about public strategies for raising awareness and implementing preventive and punitive measures. The relationship between these measures and the discourse itself has an effect linked to duty. In this sense, therefore, every citizen must understand that prevention and sanction measures are related to the pandemic context.

\section{METHODOLOGY}

The type of research in this study is qualitative, as it starts from a more subjective interpretation of information prepared with scientific content. The technical procedure used is consistent with the literature search, as it also performed a systematic review of the literature. The search in the selected databases led to the identification of articles with potential impact on the scientific community. The Web of Science and PubMed databases were chosen for searching. An integrative literature review was carried out. Integrative review has been highlighted in health research to guide review studies. The objectives were to propose a definition and purposes of the integrative review, based on the literature and identify the similarities and differences between the models of integrative review used in research about COVID-19 and individual protection masks.

For the selection of texts and their analysis, the steps of an integrative review literature (IRL) were developed, as suggested by Souza, Silva, \& Carvalho, (2010), seeking publications about COVID-19 and individual protection masks. It consists of gathering and systematizing research results on a given topic. As a theme, studies on COVID-19 and wear individual protection masks aiming to answer the following guiding questions: What does research articles on use of protective masks reveal? What is the best protective mask? What

\footnotetext{
${ }^{10}$ Modalization marks are linguistic cues left by the speaker, such as attitude verbs, conjugated in the imperative [which help to build the sense of duty) and indicate the presence of the speaker in the speech, and, consequently, his point of view. Vion explains however, that the 'erasing' of these marks, in certain propositional contents (phrases, statements) does not sometimes imply the extinction of deontic modalization.
} 
are the speeches about wearing masks talking about? What are the public strategies regarding the discourses on the use of masks and the different modalities present in acts of language? The consultation sample was determined using the following inclusion criteria: (1) most recent articles; (2) articles published in journals with blind peer review; (3) articles describing empirical studies (clinical or epidemiological) and review articles. The steps of the integrative review method were: (1) guiding question; (2) definition of the databases; (3) definition of the inclusion criteria for studies in the sample; (4) definition of search terms; (5) elaboration of the data collection instrument (table); (6) data collection.

The search keys were pandemic, individual protection masks, Personal protective equipment - PPE, and COVID-19, while looking for studies and scientific data on the subject addressed. Also, this study was carried out with a bibliometric analysis where the scientific articles found in the Scopus database were published between 2015 and 2020 (last 5 years, from the beginning of 2015 to July of 2020), according to Table 2. The choice of PubMed and Clarivate Web of Science is justified as they are a wide database, with widespread, and wide use for all areas of science.

Table 2 - Search for papers

\section{SEARCH FOR PAPERS}

\begin{tabular}{ll}
\hline Database & PubMed e Clarivate Web of Science \\
Search Type & Published papers \\
Search field & Abstract \\
Key words & mask, Covid-19, SARS-CoV-2, materials and manufacturing \\
Search within results & Engineering \\
Limit the results & $\begin{array}{l}\text { Year: 2015 to 2020 (from the beginning of } 2015 \text { to July of 2020) } \\
\text { Document type: Article } \\
\text { English language } \\
\text { Study Area: Engineering }\end{array}$ \\
\hline
\end{tabular}




\section{RESULTS AND DISCUSSION}

Analysis of the integrative review literature (IRL) data was elaborated descriptively. It was used a chart, constructed by the authors, to extract and synthesize the data of each primary study included in the review. This chart had the following information: title, objectives, study design, and main findings. Chart 1 allowed the comparison and organization of data, according to their differences, similarities, and the question of the review, which were critically analyzed.

Chart 1 - Comparison and organization of data

\begin{tabular}{|c|c|c|c|}
\hline $\begin{array}{c}\text { CITATION/Y } \\
\text { EAR/ }\end{array}$ & OBJECTIVE & TYPE OF STUDY & MAIN FINDINGS \\
\hline PAHO (2020) & $\begin{array}{l}\text { COVID-19 was characterized } \\
\text { by WHO as a pandemic }\end{array}$ & Descriptive study & $\begin{array}{l}\text { PAHO supports the development of Brazil's } \\
\text { national vaccination plan, providing } \\
\text { technical support and sharing the latest } \\
\text { scientific evidence related to OVID-19. } \\
\text { PAHO also contributes to areas such as } \\
\text { pharmacovigilance, post-vaccination } \\
\text { adverse effect surveillance, information } \\
\text { systems, risk communication, monitoring, } \\
\text { supervision, post-marketing of vaccines } \\
\text { against OVID-19 and evaluation, as well as } \\
\text { sharing successful experiences of adult } \\
\text { vaccination in other countries. }\end{array}$ \\
\hline $\begin{array}{l}\text { Zeng et at. } \\
(2020)\end{array}$ & $\begin{array}{l}\text { This study describes and } \\
\text { analyzes the epidemiological } \\
\text { characteristics of COVID- } 19\end{array}$ & $\begin{array}{l}\text { Epidemiological } \\
\text { curves and } \\
\text { simulated } \\
\text { infection curves } \\
\text { with reported } \\
\text { incubation } \\
\text { period }\end{array}$ & $\begin{array}{l}\text { Zeng et. al. (2020) points out that there is a } \\
\text { greater risk of viral transmission in usual } \\
\text { behaviors such as conversations and } \\
\text { eating. The present analysis comparing the } \\
\text { epidemiological curves in China, South } \\
\text { Korea, Italy and Spain supports the } \\
\text { importance of mask wearing by the public. } \\
\text { Analysis of the infection curve helped to } \\
\text { clarify the impact of important public } \\
\text { health events, evaluate the efficiencies of } \\
\text { prevention measures, and showed wearing } \\
\text { masks in public resulted in significantly } \\
\text { reduced daily infected cases.1 }\end{array}$ \\
\hline $\begin{array}{l}\text { Chu et al. } \\
(2020)\end{array}$ & $\begin{array}{l}\text { Investigate the optimum } \\
\text { distance for avoiding person- } \\
\text { to-person virus transmission } \\
\text { and to assess the use of face } \\
\text { masks and eye protection to } \\
\text { prevent transmission of } \\
\text { viruses. }\end{array}$ & $\begin{array}{l}\text { Systematic } \\
\text { review and meta- } \\
\text { analysis }\end{array}$ & $\begin{array}{l}\text { The findings of this systematic review and } \\
\text { meta-analysis support physical distancing } \\
\text { of } 1 \mathrm{~m} \text { or more and provide quantitative } \\
\text { estimates for models and contact tracing to } \\
\text { inform policy. Optimum use of face masks, } \\
\text { respirators, and eye protection in public } \\
\text { and health-care settings should be } \\
\text { informed by these findings and contextual } \\
\text { factors. }\end{array}$ \\
\hline
\end{tabular}




\begin{tabular}{|c|c|c|c|}
\hline $\begin{array}{l}\text { (Ministry of } \\
\text { Health, 2019, } \\
\text { n-CoV, p.11) }\end{array}$ & $\begin{array}{l}\text { On January 22, 2020, the } \\
\text { "Public Health Emergency } \\
\text { Operations Center" was } \\
\text { activated to study and } \\
\text { control the spread of the new } \\
\text { Coronavirus (COE - nCoV), a } \\
\text { strategy foreseen in the } \\
\text { National Public Health } \\
\text { Emergency Response Plan of } \\
\text { the Ministry of Health. }\end{array}$ & Descriptive study & $\begin{array}{l}\text { Human infection by } 2019-\mathrm{nCoV} \text { is a Public } \\
\text { Health Emergency of International } \\
\text { Importance. Therefore, it is a public health } \\
\text { event with immediate notification. }\end{array}$ \\
\hline Walsh (2020) & $\begin{array}{l}\text { History of pandemics in } \\
\text { humanity up to the current } \\
\text { CoviD-19 pandemic. }\end{array}$ & $\begin{array}{l}\text { Retrospective } \\
\text { study }\end{array}$ & $\begin{array}{l}\text { Imagined as flu pandemic, COVID-19 } \\
\text { started in China and spreading around the } \\
\text { world. }\end{array}$ \\
\hline Li et al. (2020) & $\begin{array}{l}\text { Initial reports of new } \\
\text { coronavirus (2019-nCoV)- } \\
\text { infected pneumonia (NCIP) } \\
\text { occurred in Wuhan, Hubei } \\
\text { Province, China in December } \\
2019 \text { and January 2020. We } \\
\text { analyzed data on the first } 425 \\
\text { confirmed cases in Wuhan to } \\
\text { determine } \\
\text { epidemiological the } \\
\text { characteristics of NCIP. } \\
\text { Information was collected on } \\
\text { demographic characteristics, } \\
\text { history of exposure, and } \\
\text { disease timelines from } \\
\text { laboratory confirmed NCIP } \\
\text { cases that had been reported } \\
\text { by 22 January 2020. }\end{array}$ & $\begin{array}{l}\text { The authors } \\
\text { collected } \\
\text { information on } \\
\text { demographic } \\
\text { characteristics, } \\
\text { exposure history, } \\
\text { and illness } \\
\text { timelines of } \\
\text { laboratory- } \\
\text { confirmed cases } \\
\text { of NCIP that had } \\
\text { been reported by } \\
\text { January 22, } 2020 \text {. } \\
\text { described } \\
\text { characteristics of } \\
\text { the cases and } \\
\text { estimated the key } \\
\text { epidemiologic } \\
\text { time-delay } \\
\text { distributions. }\end{array}$ & $\begin{array}{l}\text { The present analysis comparing the } \\
\text { epidemiological curves in China, South } \\
\text { Korea, Italy, and Spain supports the } \\
\text { importance of mask wearing by the public. } \\
\text { Analysis of the infection curve helped to } \\
\text { clarify the impact of important public } \\
\text { health events, evaluate the efficiencies of } \\
\text { prevention measures, and showed wearing } \\
\text { masks in public resulted in significantly } \\
\text { reduced daily infected cases. }\end{array}$ \\
\hline $\begin{array}{l}\text { Wu et } \\
(2020)\end{array}$ & $\begin{array}{l}\text { Descriptive analysis of the } \\
\text { epidemiological } \\
\text { characteristics of confirmed } \\
\text { cases of new coronavirus } \\
\text { pneumonia related to a } \\
\text { department store in Tianjin } \\
\text { on February 18, 2020, to } \\
\text { provide reference for the } \\
\text { formulation of prevention } \\
\text { and control strategies. The } \\
\text { related cases in a department } \\
\text { store were analyzed, } \\
\text { including ase } \\
\text { characteristics, time and } \\
\text { region distribution, clinical } \\
\text { manifestations, } \\
\text { epidemiological history and } \\
\text { transmission status. }\end{array}$ & $\begin{array}{l}\text { Observational } \\
\text { studies }\end{array}$ & $\begin{array}{l}\text { Wu et al. (2020) also confirmed in studies } \\
\text { that it is possible to have respiratory } \\
\text { transmission when speaking. } \\
\text { This was a cluster epidemic of covID-19, } \\
\text { which might be associated with the } \\
\text { exposure in the department store. }\end{array}$ \\
\hline Qiu (2020) & $\begin{array}{l}\text { Initial analysis of suspected } \\
\text { undetected set of covert } \\
\text { cases that are limited to no } \\
\text { symptoms, because an }\end{array}$ & Descriptive study & $\begin{array}{l}\text { Tthe proportion of asymptomatic people is } \\
\text { high. About } 60 \% \text { of all cases are between } \\
\text { mild symptoms and asymptomatic cases } \\
\text { that can transmit the virus to other people. }\end{array}$ \\
\hline
\end{tabular}


Protective masks in a COVID-19 pandemic period: a material analysis for the manufacture of protective masks, use, efficiency,and public strategies aimed at a protection discourse

\begin{tabular}{|c|c|c|c|}
\hline & $\begin{array}{l}\text { increasing number of } \\
\text { infected persons cannot be } \\
\text { linked to known cases of } \\
\text { OVID-19 or to trips to } \\
\text { outbreaks of epidemics. }\end{array}$ & & \\
\hline $\begin{array}{l}\text { Steffen et. al. } \\
(2020)\end{array}$ & $\begin{array}{l}\text { This study provides insight } \\
\text { into the potential } \\
\text { community-wide impact of } \\
\text { widespread face mask use by } \\
\text { members of the general } \\
\text { population. The } \\
\text { mathematical model showed } \\
\text { in this paper, parameterized } \\
\text { using data relevant to CoVID- } \\
19 \text { transmission dynamics in } \\
\text { two US states (New York and } \\
\text { Washington), suggests } \\
\text { nontrivial and possibly quite } \\
\text { strong benefits to general } \\
\text { face mask use. }\end{array}$ & $\begin{array}{l}\text { Experimental } \\
\text { study }\end{array}$ & $\begin{array}{l}\text { Steffen et. al. (2020) highlight that for both } \\
\text { cases of asymptomatic people and people } \\
\text { infected with the Coronavirus, the use of } \\
\text { masks is essential. }\end{array}$ \\
\hline $\begin{array}{l}\text { Wang et al. } \\
(2020)\end{array}$ & $\begin{array}{l}\text { This study aims to illustrate } \\
\text { transmission routes of Severe } \\
\text { Acute Respiratory Syndrome } \\
\text { Coronavirus 2 (SARS-CoV-2), } \\
\text { address the controversies } \\
\text { surrounding mask wearing, } \\
\text { and provides suggestions for } \\
\text { the use of facial masks during } \\
\text { the COVID-19 pandemic. The } \\
\text { references search was } \\
\text { conducted on March 11, using } \\
\text { three databases (PubMed, } \\
\text { CNKI, and Web of Science) } \\
\text { with the search terms } \\
\text { "COVID-19", "2019-nCoV", } \\
\text { "novel coronavirus", or } \\
\text { "SARS-CoV-2" and "mask", } \\
\text { "facial mask", or "face mask". }\end{array}$ & Descriptive study & $\begin{array}{l}\text { This study summarized that: 1) main } \\
\text { transmission routes of SARS-CoV-2 include } \\
\text { droplet, contact transmissions, and } \\
\text { possible airborne transmissions, which is } \\
\text { characterized by high proportion of cases } \\
\text { with mild symptom or asymptomatic cases, } \\
\text { strong infectivity, and a large number of } \\
\text { clusters; 2) The necessity of wearing masks } \\
\text { by the public during COVID-19 pandemic } \\
\text { has been under-emphasized; and 3) A risk } \\
\text { basis mask use strategies and compliance } \\
\text { improvement are suggested. }\end{array}$ \\
\hline $\begin{array}{l}\text { Conceição } \\
(2020)\end{array}$ & $\begin{array}{l}\text { The text provides } \\
\text { information on person-to- } \\
\text { person transmission of the } \\
\text { SARS-CoV-2 virus as well as } \\
\text { recommended individual } \\
\text { protectors. About the } \\
\text { coronavirus, the } \\
\text { transmission occurs during a } \\
\text { close exposure to a person } \\
\text { with CoVID-19, through the } \\
\text { dissemination of respiratory } \\
\text { droplets produced, when this } \\
\text { person coughs, sneezes or } \\
\text { talks. That these droplets can } \\
\text { be inhaled or land in the } \\
\text { mouth, nose or eyes of people } \\
\text { who are close by. It is also } \\
\text { known that contact of the } \\
\text { hands with a surface or object }\end{array}$ & Descriptive study & $\begin{array}{l}\text { The protection of the visors used to fight } \\
\text { the Coronavirus must guarantee good } \\
\text { sweating behavior; be made of unbreakable } \\
\text { material, with adjustable tape. (Conceição, } \\
\text { 2020) }\end{array}$ \\
\hline
\end{tabular}




\begin{tabular}{|c|c|c|c|}
\hline & $\begin{array}{l}\text { contaminated with the same } \\
\text { droplets containing SARS- } \\
\text { CoV-2, and then contact with } \\
\text { the mouth, nose or eyes, can } \\
\text { also lead to the transmission } \\
\text { of this infection. }\end{array}$ & & \\
\hline $\begin{array}{l}\text { ANVISA } \\
(2020)\end{array}$ & $\begin{array}{l}\text { Updated information panel of } \\
\text { the National Health } \\
\text { Surveillance Agency - Anvisa } \\
\text { on COVID-19. }\end{array}$ & Descriptive study & Wearing masks is a need \\
\hline BRASIL (2020) & $\begin{array}{l}\text { Legislation on the } \\
\text { Determination of the } \\
\text { mandatory use of masks, } \\
\text { within the Federal District } \\
\text { (Brazil), due to the OVID-19 } \\
\text { pandemic, caused by the new } \\
\text { coronavirus. }\end{array}$ & Descriptive study & $\begin{array}{l}\text { The mandatory use of masks is determined, } \\
\text { within the Federal District, due to the } \\
\text { pandemic of COVID-19, caused by the new } \\
\text { coronavirus (BRASIL, 2020). }\end{array}$ \\
\hline $\begin{array}{l}\text { Jefferson et al. } \\
\text { (2009) }\end{array}$ & $\begin{array}{l}\text { This text shows a } \\
\text { systematically review } \\
\text { evidence for the effectiveness } \\
\text { of physical interventions to } \\
\text { interrupt or reduce the } \\
\text { spread of respiratory viruses. }\end{array}$ & $\begin{array}{l}\text { Randomized } \\
\text { study }\end{array}$ & $\begin{array}{l}\text { Other studies have also found evidence } \\
\text { regarding the effectiveness of wearing } \\
\text { masks in reducing the risk of SARS and } \\
\text { influenza-related illnesses. Routine long- } \\
\text { term implementation of some physical } \\
\text { measures to interrupt or reduce the spread } \\
\text { of respiratory viruses might be difficult but } \\
\text { many simple and low-cost interventions } \\
\text { could be useful in reducing the spread. }\end{array}$ \\
\hline $\begin{array}{l}\text { Greenhalgh1s } \\
\text { et al. (2020) }\end{array}$ & $\begin{array}{l}\text { The text proposes two } \\
\text { hypotheses. The first is that } \\
\text { in the context of covid-19, } \\
\text { many people can be taught to } \\
\text { use masks properly and will } \\
\text { do this consistently without } \\
\text { abandoning other important } \\
\text { anti-contagion measures. } \\
\text { The second is that if political } \\
\text { will is there, mask shortages } \\
\text { can be quickly overcome by } \\
\text { repurposing manufacturing } \\
\text { capacity-something that is } \\
\text { already happening } \\
\text { informally. }\end{array}$ & Descriptive study & $\begin{array}{l}\text { There is an incentive to use masks in public } \\
\text { places, as a relevant discourse on health- } \\
\text { seeking behavior, as confirmed by } \\
\text { Greenhalgh1s et al. studies (2020). } \\
\text { Masks are simple, cheap, and potentially } \\
\text { effective. The author believes that, worn } \\
\text { both in the home (particularly by the } \\
\text { person showing symptoms) and also } \\
\text { outside the home in situations where } \\
\text { meeting others is likely (for example, } \\
\text { shopping, public transport), they could } \\
\text { have a substantial impact on transmission } \\
\text { with a relatively small impact on social and } \\
\text { economic life. }\end{array}$ \\
\hline $\begin{array}{l}\text { Feng et al. } \\
(2020)\end{array}$ & $\begin{array}{l}\text { The text discusses the need } \\
\text { for the universal use of facial } \\
\text { masks in the community } \\
\text { worldwide in the face of the } \\
\text { OVID-19 pandemic, especially } \\
\text { in China, Japan, Germany and } \\
\text { the Chinese territory of Hong } \\
\text { Kong. }\end{array}$ & Descriptive study & $\begin{array}{l}\text { It is time for governments and public } \\
\text { health agencies to make rational } \\
\text { recommendations on appropriate face } \\
\text { mask use to complement their } \\
\text { recommendations on other preventive } \\
\text { measures, such as hand hygiene. }\end{array}$ \\
\hline $\begin{array}{l}\text { Soares et al. } \\
(2020)\end{array}$ & $\begin{array}{l}\text { This text describes the } \\
\text { recommendations on the } \\
\text { rational, safe use of personal } \\
\text { protective equipment (PPE) } \\
\text { throughout the chain of care }\end{array}$ & Descriptive study & $\begin{array}{l}\text { The rational use of this equipment is } \\
\text { essential to minimize the impacts of this } \\
\text { crisis, especially regarding the workers' } \\
\text { health }\end{array}$ \\
\hline
\end{tabular}


Protective masks in a COVID-19 pandemic period: a material analysis for the manufacture of protective masks, use, efficiency,and public strategies aimed at a protection discourse

\begin{tabular}{|c|c|c|c|}
\hline & $\begin{array}{l}\text { for people with suspected or } \\
\text { confirmed contamination by } \\
\text { the new coronavirus Covid- } \\
19 \text {. }\end{array}$ & & \\
\hline $\begin{array}{l}\text { Mills; Rahah; } \\
\text { Akimova } \\
(2020)\end{array}$ & $\begin{array}{l}\text { The text is a rapid review of } \\
\text { the science of the } \\
\text { effectiveness of different face } \\
\text { mask types and coverings } \\
\text { and behavioral adherence. } \\
\text { Compiled by the Royal } \\
\text { Society and the British } \\
\text { Academy to assist in the } \\
\text { understanding of COVID-19. }\end{array}$ & $\begin{array}{l}\text { Data analysis and } \\
\text { Meta-analysis }\end{array}$ & $\begin{array}{l}\text { Face masks and coverings cannot be seen in } \\
\text { isolation but are part of 'policy packages' } \\
\text { and it is imperative to review interrelated } \\
\text { non-pharmaceutical interventions in } \\
\text { tandem including hand hygiene, sanitizers } \\
\text { and social distancing when maintaining } \\
\text { the } 2 \text { meters or } 1 \text { meter+ distancing rule is } \\
\text { not possible }\end{array}$ \\
\hline $\begin{array}{l}\text { Franco et al. } \\
(2020)\end{array}$ & $\begin{array}{l}\text { The text brings } \\
\text { recommendations on the use } \\
\text { of masks to avoid } \\
\text { contamination by Covid-19, } \\
\text { minimizing virus } \\
\text { transmissions. Surgical } \\
\text { masks and surgical } \\
\text { respiratory protection have } \\
\text { been playing an important } \\
\text { role in controlling the spread } \\
\text { of this new microorganism in } \\
\text { the world and were } \\
\text { considered an excellent and } \\
\text { accessible method for this. } \\
\text { However, it should be } \\
\text { remembered that even using } \\
\text { a mask, maintaining the } \\
\text { patient's distance (more than } \\
1 \text { meter) is particularly } \\
\text { important to reduce the risk } \\
\text { of transmission. }\end{array}$ & Descriptive study & $\begin{array}{l}\text { Surgical and respiratory protection masks } \\
\text { surgery have played an important role in } \\
\text { the } \\
\text { controlling the spread of this new } \\
\text { microorganism in the world and were } \\
\text { considered an excellent and accessible } \\
\text { method for that. However, it must be } \\
\text { remembered that, even using a mask, } \\
\text { maintaining the distance from the patient } \\
\text { (more than } 1 \text { meter) is particularly } \\
\text { important } \\
\text { to reduce the risk of transmission. }\end{array}$ \\
\hline $\begin{array}{l}\text { Quental; } \\
\text { Farah; } \\
\text { Sakahara } \\
(2020)\end{array}$ & $\begin{array}{l}\text { The text presents a new mask } \\
\text { invention pertains to a } \\
\text { method of preparing a } \\
\text { controlled rheology } \\
\text { polypropylene characterized } \\
\text { by comprising a stage of } \\
\text { mixing a propylene polymer } \\
\text { with at least one low- } \\
\text { reactivity organic peroxide. }\end{array}$ & $\begin{array}{l}\text { Experimental } \\
\text { study }\end{array}$ & $\begin{array}{l}\text { The present invention pertains to a method } \\
\text { of preparing a controlled rheology } \\
\text { polypropylene characterized by } \\
\text { comprising a stage of mixing a propylene } \\
\text { polymer with at least one low-reactivity } \\
\text { organic peroxide. The rheology } \\
\text { polypropylene of the present invention can } \\
\text { be applied for producing fibers in melt } \\
\text { blown processes, hot melt adhesives, } \\
\text { spunbonded and injection-mold-ed articles }\end{array}$ \\
\hline $\begin{array}{l}\text { Duarte; } \\
\text { Miola; } \\
\text { Cavalcante } \\
\text { (2020) }\end{array}$ & $\begin{array}{l}\text { The text reports the } \\
\text { inappropriate use of PPE and } \\
\text { the duty of health } \\
\text { institutions to develop } \\
\text { prevention and protection } \\
\text { programs to deal with } \\
\text { occupational risks. It strongly } \\
\text { suggests the use of the so- } \\
\text { called fit testing of PPE in } \\
\text { each user in Brazil, such as } \\
\text { the one performed in the } \\
\text { United States of America. }\end{array}$ & $\begin{array}{l}\text { A descriptive, } \\
\text { prospective, and } \\
\text { longitudinal } \\
\text { observational } \\
\text { study }\end{array}$ & $\begin{array}{l}\text { Though there is no convenience in reusing } \\
\text { N95 respirators, their expiration should } \\
\text { not exceed } 5 \text { days of use. }\end{array}$ \\
\hline
\end{tabular}




\begin{tabular}{|c|c|c|c|}
\hline $\begin{array}{lr}\text { The } & \text { New } \\
\text { York } & \text { Times } \\
(2020) & \end{array}$ & $\begin{array}{l}\text { The New York Times journal } \\
\text { text about coronavirus in the } \\
\text { U.S.: LATEST MAP AND CASE } \\
\text { COUNT. }\end{array}$ & Descriptive study & $\begin{array}{l}\text { United States, which does not have a } \\
\text { nationwide decree mandating the use of } \\
\text { this safety equipment, has more than } \\
3,910,300 \text { cases of contamination and } \\
142,031 \text { deaths as of July } 22,2020\end{array}$ \\
\hline $\begin{array}{l}\text { Jorge et al. } \\
(2020)\end{array}$ & $\begin{array}{l}\text { The text begins by presenting } \\
\text { a brief history of the new } \\
\text { pathogen and its forms of } \\
\text { contagion, Resolution RDC n. } \\
\text { 356, of March 23, 2020, and } \\
\text { some ANVISA guidelines for } \\
\text { health services (hospitals, } \\
\text { posts, professionals, support } \\
\text { and assistance) in relation to } \\
\text { the importance of prevention } \\
\text { and control measures. } \\
\text { Following, the results } \\
\text { obtained in the project Face } \\
\text { Shield for Life 3D are exposed } \\
\text { with the creation of a hub } \\
\text { with more than } 60 \text { makers, } \\
\text { adding more than 90 3D } \\
\text { printers, connected with the } \\
\text { purpose of obtaining a quick } \\
\text { response in the production of } \\
\text { Face Shields to professional's } \\
\text { health carefree of charge. }\end{array}$ & Descriptive study & $\begin{array}{l}\text { Through the report of the Face shields } \\
\text { collaborative production model, it was } \\
\text { evident that health professionals in } \\
\text { Salvador were helped, and knowledge was } \\
\text { disseminated to encourage other groups. }\end{array}$ \\
\hline $\begin{array}{l}\text { Gomes; } \\
\text { Barboza; } \\
\text { Fonseca } \\
(2020)\end{array}$ & $\begin{array}{l}\text { The text begins by presenting } \\
\text { recommendations to } \\
\text { manufacturing protective } \\
\text { masks to COVID-19 using 3D } \\
\text { printers. }\end{array}$ & Descriptive study & $\begin{array}{l}\text { Through a decree, ANVISA authorizes the } \\
\text { production of protectors without } \\
\text { authorization in times of calamity. In } \\
\text { addition, the production of Face Shield } \\
\text { mask must be made with } 1.75 \mathrm{~mm} \text { PLA } \\
\text { filament and common plastic, other } \\
\text { materials can be used as long as they are } \\
\text { tested. }\end{array}$ \\
\hline $\begin{array}{l}\text { Fioratti } \\
(2020)\end{array}$ & $\begin{array}{l}\text { The text relates that World } \\
\text { Health Organization (WHO) } \\
\text { started to recommend the } \\
\text { use of masks for the entire } \\
\text { population, changing its } \\
\text { initial instructions. }\end{array}$ & Descriptive study & $\begin{array}{l}\text { OMS now recommend the use of masks for } \\
\text { the entire population, which was common } \\
\text { in some regions has become mandatory in } \\
\text { others. }\end{array}$ \\
\hline $\begin{array}{l}\text { Robertson } \\
(2020)\end{array}$ & $\begin{array}{l}\text { The text relates that DIY and } \\
\text { homemade masks are } \\
\text { effective at capturing viruses. }\end{array}$ & Descriptive study & $\begin{array}{l}\text { Cambridge researchers concluded that } \\
\text { cotton T-shirts and pillowcases are the } \\
\text { best options for DIY masks. }\end{array}$ \\
\hline $\begin{array}{l}\text { Medeiros } \\
(2020)\end{array}$ & $\begin{array}{l}\text { Text from the newspaper } \\
\text { "Tribuna do Norte" with } \\
\text { information from specialists } \\
\text { for the use of PPE as a way to } \\
\text { prevent the contagion of } \\
\text { COVID-19. }\end{array}$ & Descriptive study & $\begin{array}{l}\text { Fabric masks provide a different level of } \\
\text { protection than industrial ones, and their } \\
\text { use must be combined with other } \\
\text { precautions to reduce the risk of } \\
\text { contamination. }\end{array}$ \\
\hline $\begin{array}{l}\text { Bernardes } \\
(2020)\end{array}$ & $\begin{array}{l}\text { Text from "Jornal da USP" } \\
\text { about the study and test } \\
\text { materials to produce } 1 \\
\text { million masks for hospitals. }\end{array}$ & Descriptive study & $\begin{array}{l}\text { The study carried out by USP researchers } \\
\text { showed that the materials used in the } \\
\text { retention of nanoparticles have filtration } \\
\text { efficiency ranging from } 60 \% \text { to } 97 \% \text {. }\end{array}$ \\
\hline $\begin{array}{l}\text { Smereka et al. } \\
(20200\end{array}$ & $\begin{array}{l}\text { The text analyzes the } \\
\text { efficiency of some PPE masks } \\
\text { and recommends the use of } \\
\text { protective masks as the first }\end{array}$ & Descriptive study & $\begin{array}{l}\text { Despite the divergent recommendations } \\
\text { for the use of masks, they are excellent } \\
\text { protectors against the transmission of the } \\
\text { virus. However, the respirator increases }\end{array}$ \\
\hline
\end{tabular}


Protective masks in a COVID-19 pandemic period: a material analysis for the manufacture of protective masks, use, efficiency,and public strategies aimed at a protection discourse

\begin{tabular}{|c|c|c|c|}
\hline & $\begin{array}{l}\text { protection against SARS- } \\
\text { CoV-2 transmission to } \\
\text { medical personnel. }\end{array}$ & & $\begin{array}{l}\text { the resistance to inhalation and therefore } \\
\text { must be replaced frequently. }\end{array}$ \\
\hline $\begin{array}{l}\text { Silva e Lima } \\
(2017)\end{array}$ & $\begin{array}{l}\text { The text analyzes the role of } \\
\text { the Legislative Power in the } \\
\text { production of public policies } \\
\text { in Brazil. }\end{array}$ & Descriptive study & $\begin{array}{l}\text { There is a paradox regarding legislative } \\
\text { power, because when it comes to public } \\
\text { policies, in specific articles of the } \\
\text { Constitution interpreted by the Supreme } \\
\text { Court, the representatives of the people } \\
\text { cannot fulfill their basic function of } \\
\text { legislating. The Federal Supreme Court } \\
\text { confers this power to the Executive Branch. }\end{array}$ \\
\hline Negri (2020) & $\begin{array}{l}\text { The text reports how some } \\
\text { countries are using science } \\
\text { and technology to fight the } \\
\text { epidemic, with special } \\
\text { attention to the United States } \\
\text { of America, Canada, United } \\
\text { Kingdom, Germany and } \\
\text { Brazil. }\end{array}$ & Descriptive study & $\begin{array}{l}\text { The economic and social consequences are } \\
\text { influenced by disparities in technological } \\
\text { and scientific competences between } \\
\text { countries, and this results in different } \\
\text { outcomes between them. }\end{array}$ \\
\hline $\begin{array}{l}\text { Stutt et al. } \\
(2020)\end{array}$ & $\begin{array}{l}\text { The text intention is to } \\
\text { provide a simple modelling } \\
\text { framework to examine the } \\
\text { dynamics of coVID-19 } \\
\text { epidemics when facemasks } \\
\text { are worn by the public, with } \\
\text { or without imposed 'lock- } \\
\text { down' periods. }\end{array}$ & Descriptive study & $\begin{array}{l}\text { Only lock-down periods do not prevent } \\
\text { new waves of the pandemic, but if } \\
\text { combined with the full adoption of masks } \\
\text { by the entire population, the generalized } \\
\text { tests and contact restraint, the peaks of the } \\
\text { disease would decrease. }\end{array}$ \\
\hline $\begin{array}{l}\text { O'Grady } \\
(2020)\end{array}$ & $\begin{array}{l}\text { Text from "The Washington } \\
\text { Post" Journal" on individual } \\
\text { protection initiatives } \\
\text { wearing masks for the } \\
\text { prevention of Covid-19 in the } \\
\text { United States of America and } \\
\text { other countries. }\end{array}$ & Descriptive study & $\begin{array}{l}\text { Countries that made masks mandatory } \\
\text { had low rates of virus transmission. }\end{array}$ \\
\hline Austin (1981) & $\begin{array}{l}\text { The work outlines the theory } \\
\text { of Acts of Speech, the main } \\
\text { pragmatic perspective of } \\
\text { language. The main objective } \\
\text { of the work is the analysis of } \\
\text { philological problems, } \\
\text { through the use of language } \\
\text { understood as a form of } \\
\text { action. Its strongest } \\
\text { contribution is the analysis of } \\
\text { propositions based on the } \\
\text { verification acts (linguistic } \\
\text { acts) used to describe things } \\
\text { and sentences that are used } \\
\text { to accomplish things } \\
\text { (performatives) }\end{array}$ & Descriptive study & $\begin{array}{l}\text { Discourse is action. As it is a theoretical } \\
\text { work Austin left the theory only sketched, } \\
\text { or formulated as a program, in his own } \\
\text { words; however, the need to develop it was } \\
\text { soon felt, the theory lacks a dialogical view, } \\
\text { since the notion of speech act is excessively } \\
\text { centered on the individual speaker, which } \\
\text { can lead to the non-consideration of the } \\
\text { context of use, of the language game, to use } \\
\text { Wittgenstein's terminology. However, } \\
\text { already in their versions the definitions of } \\
\text { the speech act indicate the need for } \\
\text { consideration of the interactional aspects } \\
\text { of its performance, such as, for example, } \\
\text { the contractual nature of these acts, } \\
\text { emphasized }\end{array}$ \\
\hline Neves (1996) & $\begin{array}{l}\text { In general terms, the work } \\
\text { deals with the notion of } \\
\text { modality results in a } \\
\text { semantic analysis of the } \\
\text { utterance that allows, thus, to } \\
\text { distinguish the dictum, }\end{array}$ & Descriptive study & $\begin{array}{l}\text { The modality manifests itself through } \\
\text { verbs, adverbs, nouns, grammatical } \\
\text { categories such as time, aspect and verbal } \\
\text { mode, and also adjectives, predicative } \\
\text { position. }\end{array}$ \\
\hline
\end{tabular}




\begin{tabular}{|c|c|c|c|}
\hline & $\begin{array}{l}\text { understood as propositional } \\
\text { content, and the modus, } \\
\text { understood as the modality } \\
\text { itself, the speaker's point of } \\
\text { view about what is said. In } \\
\text { other words, this is } \\
\text { equivalent to saying that, in } \\
\text { relation to what is said (the } \\
\text { dictum), there is the way } \\
\text { (modus) as what is said is } \\
\text { said. The modality manifests } \\
\text { itself through verbs, adverbs, } \\
\text { nouns, grammatical } \\
\text { categories such as time, } \\
\text { aspect and verbal mode, and } \\
\text { also adjectives, predicative } \\
\text { position. }\end{array}$ & & \\
\hline $\begin{array}{l}\text { Castilho e } \\
\text { Castilho } \\
\text { (1992) }\end{array}$ & $\begin{array}{l}\text { The work describes the } \\
\text { practical use of adverbs and } \\
\text { shows that these elements do } \\
\text { not present homogeneous } \\
\text { behaviors, both in terms of } \\
\text { their positioning in a } \\
\text { sentence and their semantic } \\
\text { properties, putting the basic } \\
\text { assumption in check. }\end{array}$ & Descriptive study & $\begin{array}{l}\text { The main contribution of the work is to } \\
\text { categorize modal adverbs in epistemic } \\
\text { modalizers express an assessment that } \\
\text { passes through the speaker's knowledge. } \\
\text { What is evaluated is the truth value of what } \\
\text { is said in the statement. Some adverbs are } \\
\text { of an assertive nature, and this property } \\
\text { can be affirmative when "the content of } \\
\text { what is stated or of what is said is presented } \\
\text { by the speaker as a fact, as beyond doubt" } \\
\text { negative (when "the content of what is said } \\
\text { is presented by the speaker as undoubtedly } \\
\text { non-factual" or relative when "the content } \\
\text { of what is said is presented as an } \\
\text { eventuality, as something that the speaker } \\
\text { believes is possible, or impossible, probable } \\
\text { or improbable". The bounding modalizers } \\
\text { do not guarantee or deny the value } \\
\text { properly of what is said, but they establish } \\
\text { conditions of truth, that is, they define the } \\
\text { scope of affirmations and negations. The } \\
\text { delimitation can be expressed from the } \\
\text { perspective of the speaker or from a } \\
\text { domain of knowledge, indicating } \\
\text { generalization or } \\
\text { restriction. }\end{array}$ \\
\hline Vion (2004) & $\begin{array}{l}\text { The concepts of modality, } \\
\text { modulizations or enunciative } \\
\text { staging are valuable tools to } \\
\text { analyze discourse dynamics. } \\
\text { Modality may be defined as a } \\
\text { reaction of the speaker } \\
\text { towards a representation } \\
\text { he/she builds in his/her own } \\
\text { speech. This reaction, which } \\
\text { results in the anchoring of } \\
\text { the representation in a } \\
\text { particular universe has little } \\
\text { to do with the concept of } \\
\text { modulization which dwells } \\
\text { on an enunciative split with }\end{array}$ & Descriptive study & $\begin{array}{l}\text { If modality contributes to the meaning of } \\
\text { the utterance, modalization makes } \\
\text { enunciative staging more complex to such } \\
\text { an extent that meaning becomes opaque } \\
\text { and the relation is blurred. In this study, it's } \\
\text { examined the way discourse develops, } \\
\text { using these tools and taking into account } \\
\text { represented discourse as well as sub- (or } \\
\text { under-) and overenunciation phenomena. }\end{array}$ \\
\hline
\end{tabular}




\begin{tabular}{|c|c|c|c|}
\hline & $\begin{array}{l}\text { the production of a reflexive } \\
\text { commentary }\end{array}$ & & \\
\hline Ducrot (1987) & $\begin{array}{l}\text { Dire et ne pas dire deepens its } \\
\text { analysis of interdiction, } \\
\text { between the lines of } \\
\text { meaning: the statement is } \\
\text { multiple of voices and plural } \\
\text { of meanings. It is not up to } \\
\text { linguistic semantics to } \\
\text { determine a single meaning } \\
\text { and explain its uniqueness. } \\
\text { Rather, it is up to him to } \\
\text { recognize the various } \\
\text { directions, which open and } \\
\text { close in his enunciation, and } \\
\text { seek to explain this polysemy } \\
\text { that constitutes discourse. } \\
\text { Multiple directions, multiple } \\
\text { voices. }\end{array}$ & Descriptive study & $\begin{array}{l}\text { The unspoken / non-seen subsidizes the } \\
\text { said / seen; that is, the non-sayable / non- } \\
\text { visible refers to the sayable / visible. But } \\
\text { the implicit does not derive from the } \\
\text { meaning of words, nor is it its complement. }\end{array}$ \\
\hline Parret (1988) & $\begin{array}{l}\text { It is an analysis of } \\
\text { interactions and language } \\
\text { games, recommended by } \\
\text { Witggeinstein, admit a series } \\
\text { of inferential strategies that } \\
\text { presuppose the insertion of a } \\
\text { rational world in the } \\
\text { collective community as a } \\
\text { foundation. }\end{array}$ & Descriptive study & $\begin{array}{l}\text { In short, pragmatics is analyzed by the } \\
\text { linguistic-contextual perspective and by } \\
\text { the orientation of understanding, by } \\
\text { rationality }\end{array}$ \\
\hline
\end{tabular}

Source: Authors' data

The integrative literature review consists of building a broad analysis of the literature, contributing to discussions about research methods and results, as well as reflections on future studies. The survey of studies using IR as a research method provided knowledge of the numerous studies carried out and the importance of an adequate systematization. Some similarities were found in the studies analyzed, the first part of article presents the same idea, that is, the delimitation of the research question based on a theme, theory or model, despite being described in different ways by the authors about the wear of masks. Most authors defend N95 as the most effective mask. About the possible differences and similarities found in the studies analyzed, the first stage presents the same idea, that is, the delimitation of the research question based on a theme "masks", despite being described in different ways by the authors.

For bibliometric analysis, in Fig.2, there is an evolution in the number of articles published over the years, which were inserted in the database of Pubmed and Clarivate Web 
of Science, on the theme "mask, Convid-19, SARS-CoV- 2, materials and manufacturing", it can be interpreted as an indication of growing interest in studying this topic.

Initially, it was defined that the type of search selected would be summaries limiting the results to the last 5 years (from the beginning of 2015 to July of 2020), the language for the abstract searching would be English, they would be the exploration fields. The keywords would be "mask and Covid-19".

This search returned a total of 725 articles by PubMed and 2897 articles by Clarivete Web of Science (only for the year 2020 due to the Covid-19 pandemic having been identified in late 2019 and spread globally over the first half of 2020), Fig.2 (a). A refinement was made in the search, the keywords were expanded to "mask, materials and manufacturing". The search field would be again "abstract", returning a total of 119 articles by PubMed and 6405 articles by Clarivete Web of Science, F ig.2 (c). The next step was to restrict articles that contained some information about the production and types of materials used in the masks, using all the keywords, "mask, COVID-19, SARS-CoV-2, materials and manufacturing", Fig .2 (b).

The search results with these filters were 2 articles by PubMed and 35 articles by Clarivete Web of Science, both from the year 2020. To finalize the filter options for this research according to Chart 1 , only articles whose area of study was engineering were chosen. Thus totaling: 1 article found by PubMed and 20 articles found by Clarivete Web of Science, Fig. 2 (d).

The growing number of articles published with the theme "mask and Covid-19", presented in Fig. 2 (a) over the past 5 years, demonstrates a greater interest in the theme of mask materials for Covid-19, despite a certain stability and less work on the manufacture and types of materials used in masks when using the search "mask, Covid-19, materials and manufacturing", Fig. 2 (c). When a complete search was made on the topic, a surprising result was obtained from just 1 article on PubMed and 20 articles by Clarivete Web of Science focused on engineering on the keywords "mask, COVID-19, SARS-CoV-2, materials and manufacturing", thus justifying the relevance of conducting a study on this topic: materials and most suitable manufactured masks for Covid-19. 
Figure 2 - Search results for articles published per year for the period from the beginning of 2015 to July of 2020 .

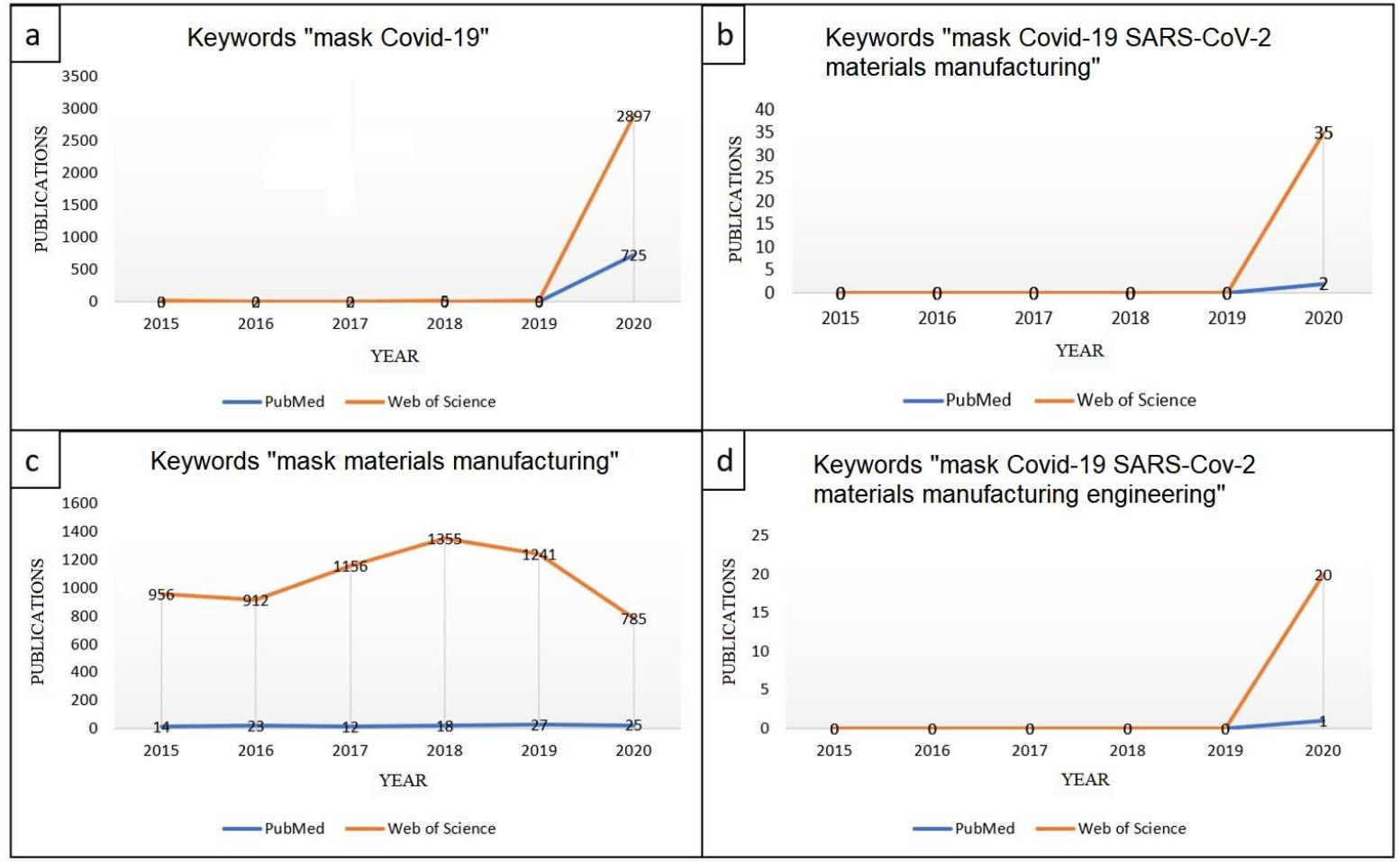

Source: Authors' data

Figure 3. Search results for articles with the terms "mask, materials and manufacturing" for the period from the beginning of the year 2015 to July of the year 2020 .

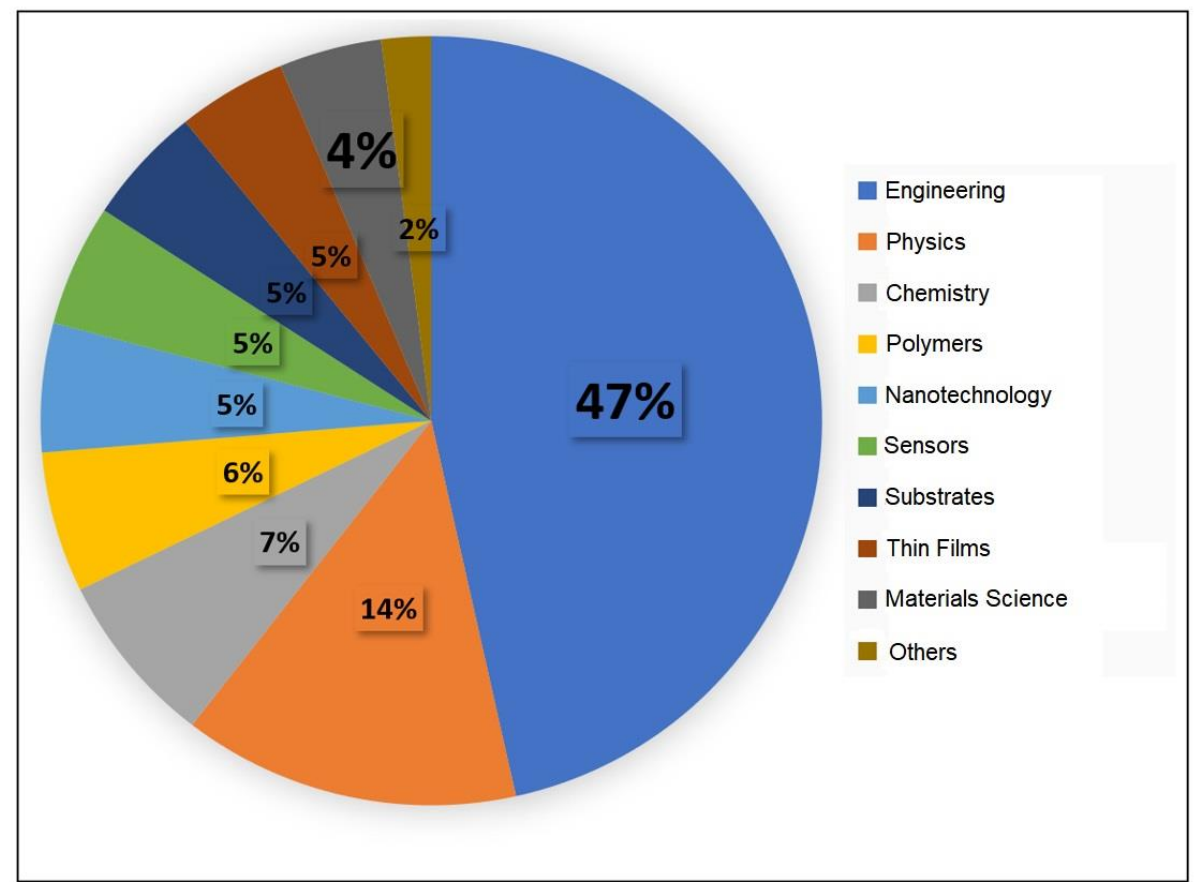

Source: Authors' data 
Clarivete Web of Science database allows a greater study concerning Fig.2 (c) and Fig.3 by analyzing the areas covered by 6405 articles presented in Clarivete Web of Science. According to the results of Fig. 3, there is a predominance of $47 \%$ of specific articles for engineering covering the keywords "mask materials manufacturing" and, of these, $4 \%$ are specific to materials science. Thus, there is the relevance of bringing a study on this theme with a focus on engineering and material sciences for the manufacture of more suitable masks for protecting against Covid-19 given the theme topicality about these two areas mentioned.

\section{CONCLUSION}

Through the bibliometric analysis, some articles were found on the topic of materials suitable for the manufacture of individual protection masks against Covid-19 in the Clarivete Web of Science and PubMed database, only 1 engineering article was found on PubMed and 20 engineering articles were found on Clarivete Web of Science for the year 2020, which demonstrates the relevance of the topic addressed in view of the large number of publications only in the year 2020 of articles covering the terms "mask and Covid-19". It was also verified that the topic is currently the focus of engineering and materials science, since the amount of research is relevant, given the high number of publications in articles on "mask and Covid19 " presented only in the year 2020.

The study of the theme "mask, materials and manufacturing" is mainly developed under the focus of engineering and material sciences, as presented by Clarivete Web of Science. The development of the present study provided the description of the materials and the analysis of what is really efficient regarding the use of masks, their relationship not only with the composition of the material, which is very important, but also with the proper use of the prevention and hygiene habits. Despite the search for more effective masks in terms of retaining viral particles, use should be prioritized, above all, by frontline professionals.

However, attention should be paid to the type of material for each mask and the type of performance of the professional. Thus, before purchasing a certain mask, it is essential to analyze whether it matches the necessary performance in the pandemic period and to adapt the prevention measures. It was also concluded that the use of a mask is an efficient public 
strategy and should be encouraged by the competent authorities, given that studies reveal the effectiveness of the correct use of individual protection masks when associated with other forms of distancing and social isolation in addition to the application of appropriate hygiene measures. Even the use of homemade masks has a fundamental role to slow the spread of the disease.

\section{REFERENCES}

ANVISA. Agência Nacional de vigilância sanitária. Covid-19: tudo sobre máscaras faciais de proteção. Retrieved from: http://portal.anvisa.gov.br/noticias/-/asset_publisher/FXrpx9qY7FbU/content/covid-19tudo-sobre-mascaras-faciais-de-protecao/219201. Accessed 24 July 2020.

AUSTIN, J. 1981. Os actos da fala: um ensaio de filosofia da linguagem. Coimbra: Almedina.

BERNARDES, J. USP testa materiais para produzir 1 milhão de máscaras para hospitais; opções caseiras também serão avaliadas. Jornal da USP, São Paulo. 6 abr 2020. Retrieved from:_https://jornal.usp.br/ciencias/cienciasexatas-e-da-terra/usp-testa-materiais-para-produzir-1-milhao-de-mascaras-para-hospitais-opcoes-caseirastambem-serao-avaliadas/. Accessed 9 July 2020.

BRASIL. Decreto ${ }^{\circ} \mathbf{4 0 . 6 4 8}$ de 23 de abril de 2020. Determina a obrigatoriedade do uso de máscaras, no âmbito do Distrito Federal, em razão da pandemia de COVID-19, causada pelo novo coronavírus. Distrito Federal. Retrieved from: http://www.sinj.df.gov.br/sinj/Norma/b7e515eba350474d85dfebff9ofdac1d/Decreto_40648_23_04_2020.html. Accessed 9 July 2020.

BRASIL. Medida provisória n. 926, de março de 2020. Altera a Lei no 13.979, de 6 de fevereiro de 2020, para dispor sobre procedimentos para aquisição de bens, serviços e insumos destinados ao enfrentamento da emergência de saúde pública de importância internacional decorrente do coronavírus. Brasília: DF. Retrieved from: http://www.planalto.gov.br/ccivil_03/_ato2019-2022/2020/Mpv/mpv926.htm. Accessed 28 July 2020.

CASTILHO, A. T.; CASTILHO, C. "Advérbios modalizadores". In: ILARI, Rodolfo (Org.). Gramática do português falado. Vol. 2. Campinas: Ed. Unicamp/FAPESP, 1992, p.213-261.

CHU, D. K; AKL, E.A; DUDA, S; SOLO, K.; YAACOUB, S.; SCHÜNEMANN, H.J. Physical distancing, face masks, and eye protection to prevent person-to-person transmission of SARS-CoV-2 and COVID-19: a systematic review and meta-analysis. The Lancet. Vol 395, 2020, June 27.

CONCEIÇÃO, C.; LOPES, D; RAMOS, J.; CRISTÓVÃO, J.P.; VIEIRA, M.L.; Pingarilho, M.; Ferreira, P.; Parreira, R. Covid-19: óculos de proteção e viseiras. Retrieved from:https://www.ihmt.unl.pt/covid-19-oculos-deprotecao-e-viseiras/. Accessed 24 July 2020.

DO PORTAL DO GOVERNO. Tire suas dúvidas sobre o uso obrigatório de máscara em SP: a partir de julho, pessoas e estabelecimentos poderão ser multados pela Vigilância Sanitária; valores custearão cestas do Alimento Solidário. SP Notícias, 01 jul. 2020. Retrieved from: https:www.saopaulo.sp.gov.br/spnoticias/tire-suasduvidas-sobre-o-uso-obrigatorio-de-mascara-em-sp/. Accessed 30 July 2020.

DUARTE, L.R.P.; Miola, C.E; Cavalcante, N.J.F. Estado de conservação de respiradores PFF-2 após uso na rotina hospitalar. Revista da escola de Enfermagem da USP. 2010. Retrieved from:https://www.scielo.br/scielo.php?script=sci_arttext\&pid=S0080-62342010000400022. Accessed 27 July 2020. 
DUCROT, O. o dizer e o dito. Campinas: Pontes, 1987.

EUROPEAN COMITTEE FOR STANDARDIZATION. EN 149:2001+A1:2009. Respiratory protective devices -Filtering half masks to protect against particles - Requirements, testing, marking. Retrieved from: https://standards.cen.eu/dyn/www/f?p=204:110:0FSP_PROJECT:32928\&cs=1B0AB06FEB70E43960D46D1198C37 CC09. Acessed 23 dez 2020.

FENG, S., Shen, C., Xia, N., Song, W., Fan, M., Cowling, B.J. Rational use of face masks in the COVID-19 pandemic. The Lancet Respiratory Medicine, 2020

FIORATTI, C. OMS, finalmente passa a recomendar uso de máscaras. Super Abril. 5 jun.2020. Retrieved from: Retrieved from:https://super.abril.com.br/saude/oms-finalmente-passa-a-recomendar-uso-de-mascara/. Accessed 22 July 2020.

FRANCO, A. G.; FRANCO, A.B.G; CARVALHO, G.A.P.; RAMOS, E.V.; DIAS, S.C. Máscaras cirúrgicas em tempos de coronavírus. InterAmerican Journal of Medicine and Health, 2020. Retrieved from: DOI: https://doi.org/10.31005/iajmh.v3i0.73. Accessed 27 July 2020.

GOMES, L. C. D.; BARBOZA, R. A. B.; FONSECA, S.A. Materiais para fabricação de máscara "face shield" em impressora 3D de proteção ao CovID-19. 31 mar. 2020. Retrieved from:https://bibliotecas.sebrae.com.br/chronus/ARQUIVOS_CHRONUS/bds/bds.nsf/fb56faa9a6ac0d12781a4c 0a16f07a6e/\$File/19496.pdf. Accessed 29 July 2020.

GREENHALGH, T., SCHMID, M.B., CZYPIONKA, T., BASSLER, D., GRUER, L. Face masks for the public during the covid-19 crisis. BMJ Clinical research, ed. 369, 2020, m 1435.

HEALTHLINE. What Is $\mathrm{R}_{0}$ ? Gauging Contagious Infections. Retrieved from:https://www.healthline.com/health/r-nought-reproduction-number. Acessed: 22 dez. 2020.

JEFFERSON, T., DEL MAR, C., DOOLEY, L., FERRONI, E., AL-ANSARY, L.A., BAHAMDAN, S.A., BAWAZEER, G.A., VAN DRIEL, M.L., FOXLEE, R., RIVETTI, A. Physical interventions to interrupt or reduce the spread of respiratory viruses: systematic review. Br. Med. J. 339, b3675, 2009.

JORGE, E. F.; TANURE, J.M.; BARRETO, E.; AZEVEDO, V.; LOBATO, P.; BRITO, L; ARAUJO, M.; FERNANDES, A. GARCEZ, B.; FERRAZ, F.; SABA, H. 2020. Face Shield for Life 3D: produção colaborativa, usando a comunidade de makers, dos protetores faciais padrão RC3 para os profissionais de saúde em Salvador. Cadernos de Prospecção, v. 13, n. 2 COVID-19, p. 513. Retrieved from: DOI:_http://dx.doi.org/10.9771/cp.v13i2.COVID-19.36174. Accessed 28 July 2020.

LI, Q.;GUAN, X.; WU, P.; WANG, X.; ZHOU, L.TONG, Y.; REN, R.; LEUNG, K.S.M.; LAU, E.H.Y.; WONG, J.Y; XING, X.; XIANG, N.; WU, Y.; LI, C.; CHEN, Q. LI, D. ; LIU, T.; ZHAO, J.; LIU, M.; TU, W.; CHEN, C.; JIN, L.; YANG, R.; WANG, Q.; ZHOU, S.; WANG, Y.; LIU, H.; LUO, Y.; LIU, Y.; SHAO G.; LI, H.; TAO, Z.; YANG, Y.; DENF, Z.; LIUZ, B.; MA, Z; ZHANG, Y.; SHI, G.; LAM, T.T.Y.; WU J.T.; GAO, G.F.; COWLING, B.J;; YANG, B.; LEUNG, G.M.; FENG, Z. 2020. Early Transmission Dynamics in Wuhan, China, of Novel Coronavirus-Infected Pneumonia. N Engl. J. Med., 2020, mar 26; 382 (13): 1199-1207. Retrieved from: DOI 10.1056/NEJMoa 2001316 Epub., jan. 29.

MANCUSO, A. C. B. Métodos Bayesianos em Metanálise. Monografia apresentada para obtenção do grau de Bacharel em Estatística. Universidade Federal do Rio Grande do Sul. Instituto de matemática. Departamento de estatística, $2010 . \quad$ Retrieved from: https://www.lume.ufrgs.br/bitstream/handle/10183/29108/000775678.pdf?sequence=1. Acessed 23 dez.2020.

MEDEIROS, J. 2020. Especialistas orientam sobre a fabricação de máscaras caseiras. Tribuna do Norte, Natal. 4 mai 2020. Retrieved from:http://www.tribunadonorte.com.br/noticia/especialistas-orientam-sobre-afabricaa-a-o-de-ma-scaras-caseiras/476708. Accessed 9 July 2020.

MILLS, M.; RAHAL, C.; AKIMOVA, E. Face masks and coverings for the general public: Behavioural knowledge, effectiveness of cloth coverings and public messaging. The Royal Society, 26 jun., 2020. 
Protective masks in a COVID-19 pandemic period: a material analysis for the manufacture of protective masks, use, efficiency,and public strategies aimed at a protection discourse

MINISTÉRIO DA SAÚDE. Protocolo de tratamento do Novo Coronavírus (2019-nCoV). Secretaria de Atenção Especializada à Saúde. Departamento de Atenção Hospitalar, Urgência e Domiciliar. Brasília - DF, 2020. Retrieved from:http://das.prodegesp.ufsc.br/files/2020/02/protocolo-tratamento_coronavirus-individ-1-1.pdf. Acessed 27 July 2020.

MINISTÉRIO DA SAÚDE. Coronavírus - COVID-19. o que você precisa saber. Retrieved from:https://coronavirus.saude.gov.br/. Acessed 27 July 2020.

NEGRI, F. de; KOELLER, P. Políticas públicas para pesquisa e inovação frente à Covid-19. 20 mai 2020. Retrieved from:https://www.ipea.gov.br/cts/pt/central-de-conteudo/artigos/artigos/192-politicas-publicaspara-pesquisa-e-inovacao-frente-a-covid 19\#_ftn9. Accessed 23 July.

NEVES, M.H. M. A modalidade. In: KOCH, I. V. (Org.). Gramática do português falado. Vol. 6. São Paulo: Unicamp/FAPESP, 1996. p. 163-195.

NEVES, M. H. M. Texto e gramática. São Paulo: Contexto, 2006.

O' GRADY, S. Unlike the United States, more and more countries are making masks mandatory. 20 jul 2020 Retrieved from:https://www.washingtonpost.com/world/2020/07/20/mandatory-face-mask-requirementsglobal-coronavirus/. Accessed 23 July 2020.

OPAS. Folha informativa - COVID-19 (doença causada pelo novo coronavírus). 2020. Retrieved from:https://www.paho.org/bra/index.php?option=com_content\&view=article\&id=6101: covid19\&Itemid=875. Accessed 23 July 2020.

PARRET, H. Enunciação e pragmática. Trad. Eni Pulcinelli Orlandi et al. Campinas: Editora da UNICAMP, 1988.

PRESIDÊNCIA DA REPÚBLICA. 2020. Planalto. Covid-19 Lei que torna obrigatório o uso de máscara é sancionada: Medida visa a proteção durante a pandemia de covid-19. 03 July 2020. Retrieved from:https://www.gov.br/planalto/pt-br/acompanhe-o-planalto/noticias/2020/07/lei-que-torna-

obrigatorio-o-uso-de-mascara-e-sancionada. Accessed 02 Aug 2020.

QIU, J. Covert coronavirus infections could be seeding new outbreaks. Nature, 2020.

QUENTAL, A. C.; FARAH, M.; SAKANHARA, R. M. Method for producing controlled rheology polypropylene, polypropylene, use thereof and manufactured articles. U.S. Patent Application, n. 15/103,560, 27 out. 2016. Retrieved from:http://www.freepatentsonline.com/y2016/0311944.html. Accessed 27 July 2020.

ROBERTSON, P. 2020. What Are The Best Materials for Making DIY Masks?, 3 ago.2020. Retrieved from: https://smartairfilters.com/en/blog/best-materials-make-diy-masks-virus/. Accessed 9 July 2020.

SILVA, S.S.; LIMA, E.M. 2017. Os limites do poder legislativo para atuar sobre políticas públicas. Revista de Direitos Sociais e Políticas Públicas. Brasília, v. 3, n. 1, p. 101 -118, Jan/Jun. 2017.

SOARES, S.; SOUZA, N.; SILVA, K.; CÉSAR, M.; SOUTO, J.; LEITE, J. 2020. Pandemia de Covid-19 e o uso racional de equipamentos de proteção individual. Revista Enfermagem UERG. 2020. Retrieved from: DOI: https://doi.org/10.12957/reuerj.2020.50360. Accessed 27 July 2020.

SMEREKA, J.; RUETZLER, K.; SZARPAK, L. FILIPIAK, K. J; JAQUSZEWSKI, M. Role of Mask/Respirator Protection Against SARS-CoV-2. International Anesthesia Research Society. July $2020 \bullet$ Volume $131 \cdot$ Number 1, 2020.

STEFFEN, E.; EIKENBERRY, M.M.; ENAHORO, I; TIN, P.; KEENAN, E; YAN KUANG, E.; ABBA, B.G. 2020. To mask or not to mask: Modeling the potential for face mask use by the general public to curtail the COVID-19 pandemic. Infectious Disease Modelling, 5, 2020, p.293-308.

STUTT, R; RETKUTE, R.; BRADLEY, M.; GILLIGAN, C.; COLVIN, J. 2020. A modelling framework to assess the likely effectiveness of facemasks in combination with 'lock-down' in managing the COVID-19 pandemic. 10 june.2020. 
Proc. R. Soc. A. 476: 20200376. Retrieved from: DOI: https://doi.org/10.1098/rspa.2020.0376. Accessed 20 July 2020.

THE NEW YORK TIMES. Coronavirus in the U.S.: Latest Map and Case Count. 22 jul 2020. Retrieved from:https://www.nytimes.com/interactive/2020/us/coronavirus-us-cases.html. Accessed 23 July 2020.

THE NEW YORK TIMES. Which mask should you wear? 17 abr. Retrieved from: https://www.nytimes.com/interactive/2020/health/coronavirus-best-face-masks.html. Accessed 29 July 2020.

VALENTE, J. 2020. Covid-19: Brasil adota uso de máscaras como política de saúde pública. Agência Brasil. Brasília, 27 abr. 2020. Retrieved from:https://agenciabrasil.ebc.com.br/geral/noticia/2020-04/covid-19-brasiladota-uso-de-mascaras-como-politica-de-saude-publica. Accessed 31 July 2020.

VION, M. R 2004. Modalités, modalisations et discours représentés. Langages, 38-156: 96-110, 2004.

WALSH, B. 2020. Covid-19: The history of pandemics. BBC, 25 mar. 2020. Retrieved from:https://www.bbc.com/future/article/20200325-covid-19-the-history-of-pandemics. Accessed 29 July 2020.

WANG, J.; PAN, L.; TANG, S.; JI, J.S; SHI, X. 2020. Mask use during COVID-19: A risk adjusted strategy. Environmental Pollution, 266, 2020, 115099.

WU, W., LI, Y., WEI, Z., ZHOU, P., LYU, L., ZHANG, G., ZHAO, Y., HE, H., LI, X., GAO, L., ZHANG, X., LIU, H., ZHOU, N., GUO, Y., ZHANG, X., ZHANG, D., LIU, J., ZHANG, Y.B. 2020. Investigation and analysis on characteristics of a cluster of COVID-19 associated with exposure in a department store in Tianjin. Chin. J. Epidemiol. 41, 2020, p.489-493.

ZENG, N. A; ZEWEN, L.A; NG, S. B.C; CHEN, D. A.; ZHOU, H.A. Epidemiology reveals mask wearing by the public is crucial for COVID-19 control. Medicine in Microecology, 4, 2020, p. 100015.

\section{(cc)) BY}

Este trabalho está licenciado com uma Licença Creative Commons - Atribuição 4.0 Internacional. 